\title{
Local-Scale Adaptations: A Modeled Assessment of Soil, Landscape, Microclimatic, and Management Factors in Norse Home-Field Productivities
}

\author{
W. Paul Adderley, ${ }^{1,}{ }^{*}$ Ian A. Simpson, ${ }^{1}$ and Orri Vésteinsson ${ }^{2}$ \\ ${ }^{1}$ School of Biological and Environmental Sciences, University of Stirling, \\ Stirling FK9 4LA, Scotland, United Kingdom \\ ${ }^{2}$ Institute of Archaeology Iceland, Bárugötu 3, 101 Reykjavik, Iceland
}

\begin{abstract}
Adaptation of farming practices to inherent site conditions was essential to the success of Norse colonization in pristine landscapes. A key factor in the initial success of colonization, or landnám, of Iceland was management of the area adjacent to the domestic dwelling, the home-field, to provide fodder for over-wintering livestock. In this paper we examine three settlement home-fields in the Mývatn and Laxá valley area of northeast Iceland. Contemporary evidence reveals a distinct climatic toposequence together with differences in the nature of the inherent soils between sites. By considering the influence of these differences, microscale adaptations in early land management practices in the production of hay are sought within a tightly defined chronological context. Using an integrated agroecosystem modeling approach, the factors affecting long-term sustainability of hay production in the Norse home-field are examined. Results indicate that regional-level climate differences will have an impact on production, especially pronounced cold periods. It is also clear that small-scale climate factors, as well as inherent soil differences between sites influenced productivity for the Norse farmer. However, productivities overall are at subsistence level, emphasizing the need for optimized land management to sustain home-field production. After examining different management scenarios, it is apparent that the effect of an increased rate of manuring will be most apparent during the first century of settlement; thereafter the effect is relatively diminished. (C) 2008 Wiley Periodicals, Inc.
\end{abstract}

\section{INTRODUCTION}

The success of Norse settlement (landnám-Old Norse: land take) across the North Atlantic region was dependent on the development of sustainable food resources from the new environments that settlers experienced. In most settlement locations, agrarian production combined livestock grazing of extensive rangeland areas with management of a home-field area (McGovern et al., 2007; Thomson \& Simpson, 2007; Edwards et al., 2005; Simpson et al., 2004). The Norse home-field, the managed field area adjacent to and surrounding the farm site, was a key

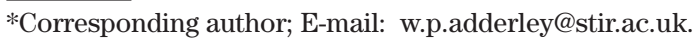

Geoarchaeology: An International Journal, Vol. 23, No. 4, 500-527 (2008)

(C) 2008 Wiley Periodicals, Inc.

Published online in Wiley Interscience (www.interscience.wiley.com). DOI:10.1002/gea.20228 
element since in many locations it produced much of the fodder required to overwinter livestock-in particular, milking cows, which formed the basis of the dairy economy of the Norse settlers (Eggertsson, 1998; Vésteinsson, 1998; Vésteinsson, McGovern, \& Keller, 2002). Creation, management, and productivity of home-field areas has been considered a key part of the initial success and long-term sustainability of early settlements across the North Atlantic region (Adderley \& Simpson, 2005, 2006; Simpson et al., 2002). Considering the varying environmental challenges faced by Norse settlers across the North Atlantic, it is becoming apparent that there were broad-scale geographic differences in the management and utilization of home-field areas. These differences are seen to arise due to a variety of factors, including climatic thresholds and soil fertility shaping cereal crop production patterns in Iceland (Simpson et al., 2002), finite areas of suitable lowland in the Faeroe Islands (Adderley \& Simpson, 2005), and soil moisture deficits in Greenland (Adderley \& Simpson, 2006).

Local scale factors influencing home-field productivities (and thus livestock densities), and the associated implications for social hierarchies, are poorly understood. In this paper we set out to identify the contributions of climate, soil, altitude, aspect, and adaptive management influencing home-field grassland productivity in northern Iceland, focusing on the Norse settlement period from ca. A.D. 870 but running our analyses through to the onset of intensive modern farm management ca. A.D. 1950. To do so we consider three Norse home-field areas associated with contrasting settlement sites, temporally constrained through tephrochronology and in relatively close proximity to each other along the Mývatn and Laxá valley area of northeast Iceland (Figure 1). We integrate contributory factors within the CENTURY agroecosystem model (Parton, Stewart, \& Cole, 1988; Metherell, et al., 1993), a model well verified through both soil analyses and the use of historical data in North Atlantic contexts (Adderley et al., 2000; Simpson et al., 2002; Adderley \& Simpson, 2005). In our discussion we highlight the way in which model-based analyses permit assessments to be made of the relative importance of these contributory factors over extended periods of time and for different Norse and later historic management scenarios. The paper concludes by drawing attention to variances in Norse and later land management practices in respect to both microclimatic factors between sites and the relative sociopolitical status of the settlements themselves.

\section{ENVIRONMENT AND MANAGEMENT RECONSTRUCTIONS}

\subsection{Field Sites}

Home-fields associated with three Norse settlement sites along the Laxá Valley are considered (Figure 1): Höfðagerði $\left(65^{\circ} 55.7^{\prime} \mathrm{N}, 17^{\circ} 26.5^{\prime} \mathrm{W}\right)$, Hofstaðir $\left(65^{\circ} 36.4^{\prime} \mathrm{N}\right.$, $\left.17^{\circ} 10.2^{\prime} \mathrm{W}\right)$, and Oddastaðir $\left(65^{\circ} 28.4^{\prime} \mathrm{N}, 17^{\circ} 04.7^{\prime} \mathrm{W}\right)$. These three sites vary in elevation from Höfðagerði at $37 \mathrm{~m}$ asl (above sea level), to Hofstaðir at $250 \mathrm{~m}$, to Oddastaðir at $350 \mathrm{~m}$, therefore forming both a toposequence and a radial sequence from the seacoast (Figure 2). Soils at these sites are well drained to imperfectly drained silt loams and fine sandy silt loams up to $100 \mathrm{~cm}$ in thickness. They are developed on a Pleistocene-age palagonite formation and are classified as andosols derived from 


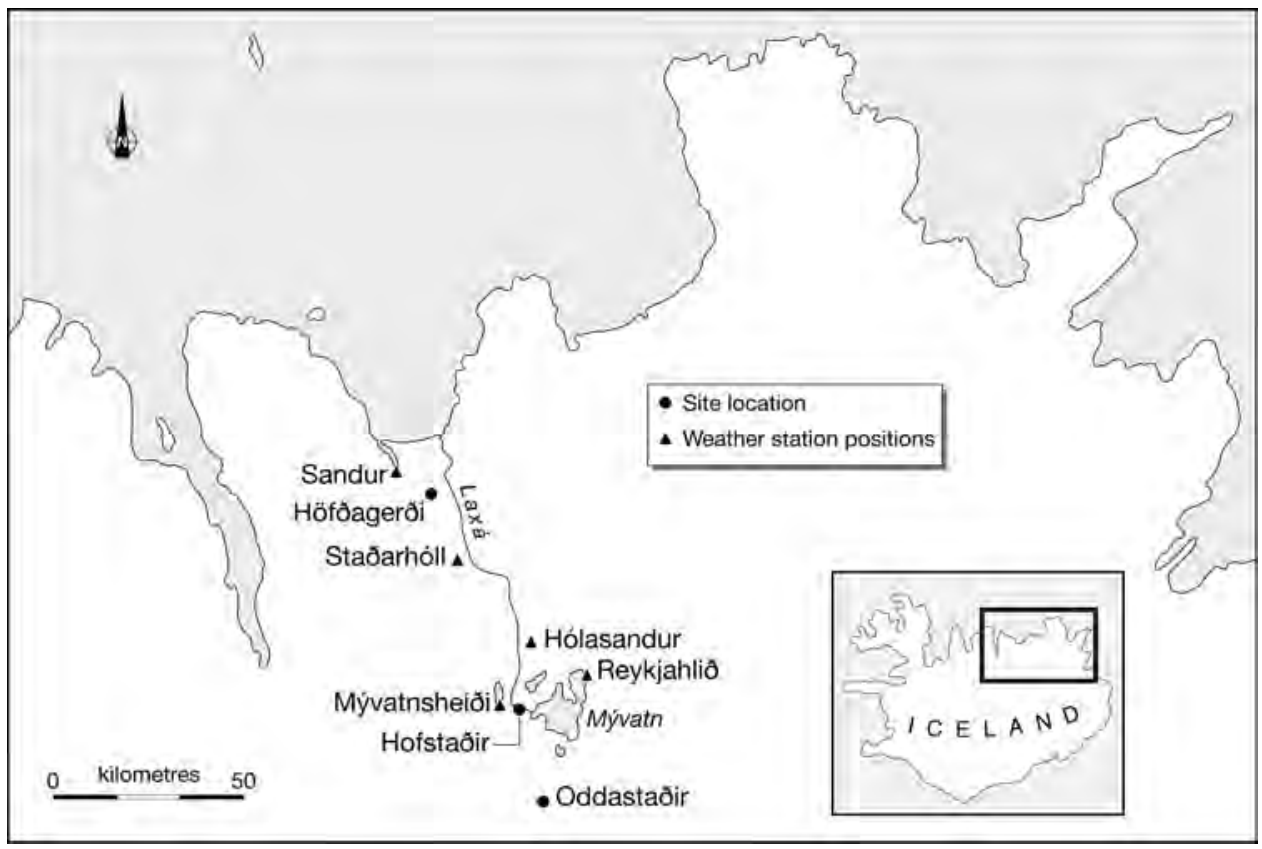

Figure 1. Map of the Laxá Valley and Mývatn Lake area, northeast Iceland, showing locations of study sites and climate stations.

tephra and aeolian materials of various origins (Jóhannesson, 1960; Soil Survey Staff, 1998; IUSS Working Group WRB, 2006). Historical tephrochronologies are well established for the study region and the study sites. Discrete landnám Veiðivötn, A.D. 871 \pm 2 , and Veiðivötn, A.D. 950, tephra horizons allow distinction between presettlement and post-settlement phases of accumulation (Table I). Where present, historic tephras (Hekla 1104, Hekla 1158, Katla 1262, Hekla 1300, Veiðivötn 1477, and Veiðivötn 1717) make possible further assessment of soil conditions during Viking, medieval, and later phases of settlement (Sigurgeirsson, 1995, 2001, pers. comm.; Simpson, Milek, \& Guðmundsson, 1999; Simpson et al., 2003, 2004). Pre-settlement tephras include Hekla 4 (H4: ca. 4000 yr B.P.), Hekla 3 (H3: ca. 2800 yr B.P.), Hverfjall (Hv: ca. 2500 yr B.P.), and the so-called "b" and "c" tephras (A.D. 700/600), providing baseline chronological contexts prior to settlement.

Table I. Site chronologies of Norse settlements at Höfðagerði, Hofstaðir, and Oddastaðir in the Mývatn and Laxa valley area, northeast Iceland.

\begin{tabular}{lcc}
\hline Site & Date of Settlement & Date of Abandonment \\
\hline Höðagerði & $\sim$ A.D. 870 & $<$ A.D. 1477 \\
Hofstaðir & $\leq$ A.D. 950 & Continuous occupation to present day \\
Oddastaðir & <A.D. 950 & $<$ A.D. 1300 \\
\hline
\end{tabular}




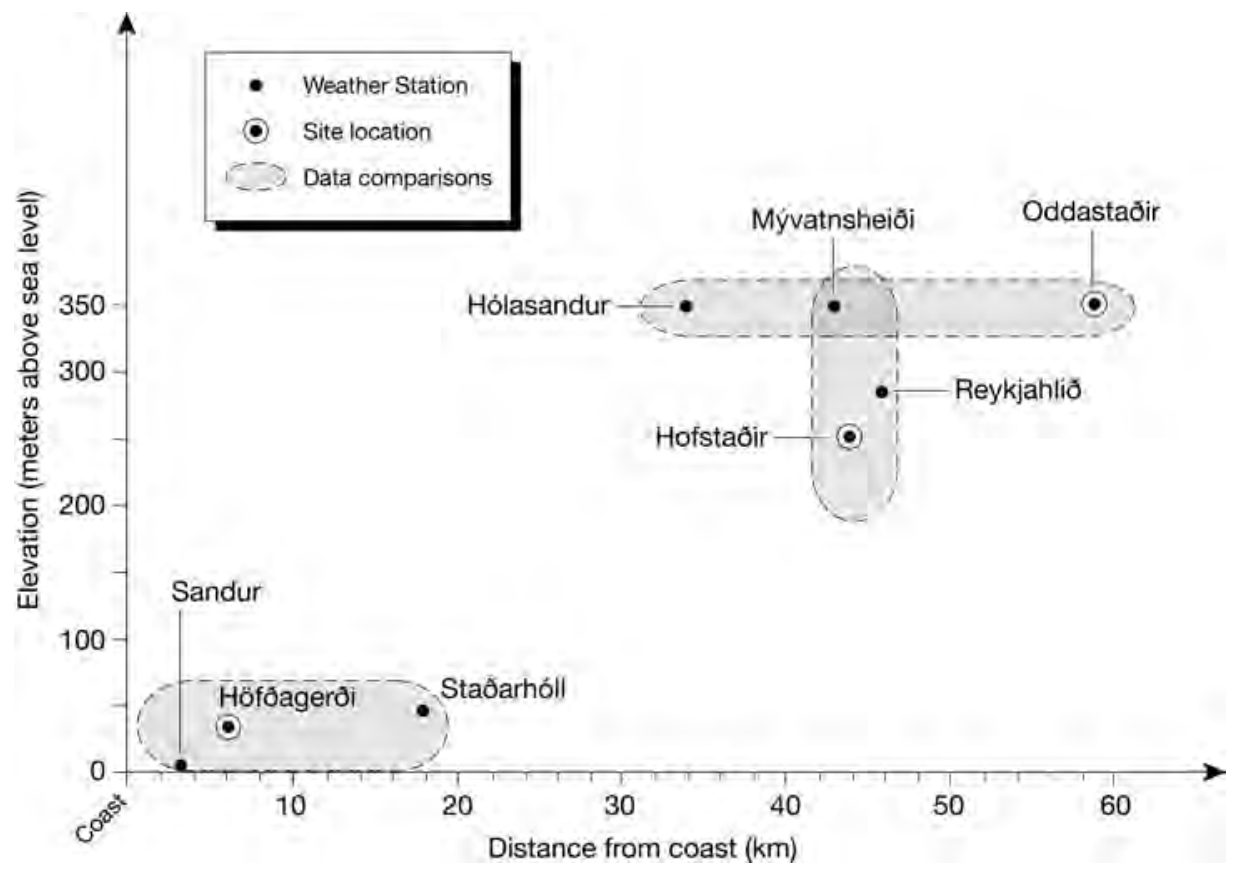

Figure 2. Toposequence showing relative altitudinal positions of study sites and climate stations.

Archaeological survey and excavations at the Höfðagerði settlement indicate a number of substantial Viking and medieval structures enclosed within a home-field of ca. 4 ha. Viking structures, including a long house ca. $25 \mathrm{~m} \times 10 \mathrm{~m}$, were abandoned prior to 1104, and the settlement changed focus within the home-field area before abandonment some time before 1477. Similarly, the main home-field boundary, which is located on and truncates the landnám tephra, was remodeled post-1300 and fell into disrepair before 1477 (Aldred, 2004).

Excavation of structures at the Hofstaðir site demonstrate a large hall-like building, nearly $40 \mathrm{~m}$ long and $9 \mathrm{~m}$ wide, immediately postdating the A.D. $\sim 950$ tephra together with adjacent pit houses and associated artifacts. Abandonment of this location for an adjacent and later location, yet to be excavated, occurred before the fall of the 1104 tephra; the site was occupied from shortly after landnám through to the present day, with the presence of an early small church structure confirming its high status (Simpson, Milek, \& Guðmundsson, 1999; Lucas, 2003; Friðriksson, Vésteinsson, \& McGovern, 2004). Excavation of a boundary wall enclosing the ca. 4.5ha home-field has indicated construction well before the A.D. 1477 tephra with two major earlier repairs (Einarsson, Hansson, \& Vésteinsson, 2002).

Oddastaðir is located in the interior of the Mývatnssveit region and borders an area that has suffered from widespread soil erosion. Archaeological survey has highlighted a number of structures of Viking and later age enclosed within a home-field of ca. 2.5 ha. Preliminary excavations have suggested that successive phases of 
occupation and abandonment characterize the site, which was occupied by the 11 th century and abandoned by 1300 , although reoccupied for a short time in the 17th century (Vésteinsson, 2004).

In addition to forming a toposequence, these three sites can be considered to represent different ages and statuses within the Norse settlement landscape, with Höfðagerði an early mainstream farm, Hofstaðir a high-status farm, and Oddastaðir a peripheral farm (Table I). At Höfðagerði and Oddastaðir, six soil profiles were exposed on transect lines across the home-field. At Hofstaðir, because of the number of buried turf structures in the home-field, only two profiles were exposed to ensure avoidance of archaeological structure locations. One representative profile from each of the sites was selected for subsequent analyses. Soil profiles were described in terms of their Munsell color and texture (Hodgson, 1976), noting as well the occurrence of fine bone and charcoal fragments; special attention was focused on tephra materials to establish a robust chronology of soil development. Undisturbed samples were taken in Kubiëna tins, and corresponding bulk samples were taken for physical and chemical analysis.

\subsection{Climate}

In order to examine the differences in climatic factors among the three sites, contemporary high-resolution data sets were compared from a set of weather stations along the Laxá valley and around Lake Mývatn (Figure 1). The modeling study requires proxy records of climate including paleotemperatures and, if possible, palaeoprecipitation. Climatic conditions at these three field sites have been assessed by considering both long-term fluctuations at a regional level and by examining local variations. It is widely noted that climatic conditions were generally warmer at the time of the Norse settlement (A.D. 870 onwards), with cooler conditions becoming established in the 13th century (Ogilvie, 1984; Ogilvie, Barlow, \& Jennings, 2000). At the regional North Atlantic level, a relationship between the Greenland ice core record and historical evidence of climate in Iceland has been previously demonstrated (Sveinbjörnsdóttir, 1993), and while anomalies around A.D. 1500 and A.D. 1700 have been described (Guðmundsson, 1997), historical climatic evidence for the time of settlement is generally consistent with these long-term trends.

Examining instrumental data from the 20th century onwards, it is clear that the rainfall pattern in northeastern Iceland is distinctly different from that elsewhere in Iceland. Since the whole region is in the rain shadow for prevailing wind directions created by the Vatnajökull glacier, total annual precipitation is low $\left(\sim 400 \mathrm{~mm} \mathrm{a}^{-1}\right)$ compared to southern and western Iceland (1000-4000 $\mathrm{mm} \mathrm{a}^{-1}$ ) (Einarsson, 1979). Likewise, the period of highest rainfall in this region is in mid- to late summer, while in south and west Iceland this is in early winter (Bjornsson \& Jonsson, 2004). From empirical observations, winter season temperatures are related to vegetation growth the following year, with cold winters reported to reduce vegetation growth through the following season (Bergpórsson, 1988). For model input, local weather measurements have been collated from published and unpublished data sets for five measurement sites in the Mývatn and Laxá valley area. Calculated climate normals are shown in Table II (Veðurstofa Íslands, 2005, pers. comm.). These sites are at Sandur 


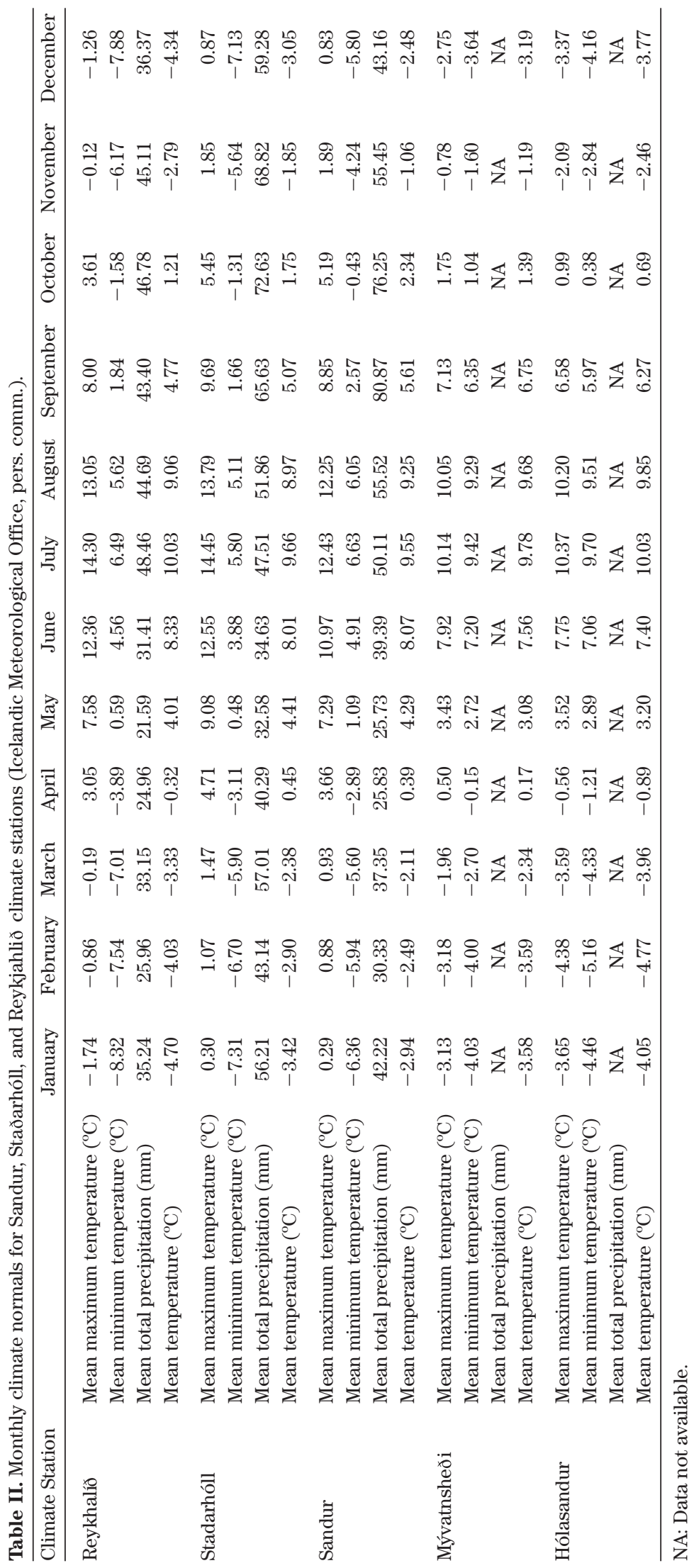


( $65^{\circ} 57^{\prime} \mathrm{N}, 17^{\circ} 33^{\prime} \mathrm{W} ; 3 \mathrm{~m}$ Above Sea Level), Staðarhóll ( $65^{\circ} 49.2^{\prime} \mathrm{N}, 17^{\circ} 20.8^{\prime} \mathrm{W} ; 42 \mathrm{~m}$ asl), Hólasandur ( $65^{\circ} 42^{\prime} \mathrm{N}, 17^{\circ} 06^{\prime} \mathrm{W}$; $350 \mathrm{~m}$ asl), Mývatnsheiði $\left(65^{\circ} 36.9^{\prime} \mathrm{N}, 17^{\circ} 13.0^{\prime} \mathrm{W} ; 350 \mathrm{~m}\right.$ asl), and Reykjahlið (65 $39^{\prime} \mathrm{N}, 16^{\circ} 55^{\prime} \mathrm{W}, 285 \mathrm{~m}$ asl; Figures 1 and 2). For purposes of modeling of early-Norse hay meadow management, reconstructed annual temperatures based on historical sea-ice data (Bergpórsson, 1969) have been scaled to modern instrument-based data. For each site, from the modern climate normals, temperature measurements have been used to scale the long-term regional temperature trend to localized conditions. Using the modern monthly temperature ranges, the annualized data of Bergpórsson (1969) are then extrapolated to a monthly time step. In the absence of long-term proxy records of snow and rainfall for the modeling study, rather than generate a stochastic variable, the local short-term precipitation data have been used by rewinding and repeating these throughout the modeled period.

In addition to the altitudinal and latitudinal differences between sites, the sites are potentially shaded at low sun angles. This is perhaps most relevant to Höfðagerði, which lies in a valley center. With the angle of incidence of the sun's radiation also varying with latitudinal position, the compounded effect of latitudinal difference between sites and the relationship between topography and the angle of incidence of incoming sunlight was considered by examining the incoming solar radiation (insolation) to the home-fields using GIS methods. ArcView GIS software (ESRI, 2006) and topographic information from a $25 \mathrm{~m}$ square digital elevation model, mean insolation values were calculated for the Laxá Valley and Mývatn region (Figure 3) using an extension to ArcView (Fu \& Rich, 2002; Kumar, Skidmore, \& Knowles, 1997), thereby allowing each site to be characterized.

\subsection{Soil Analysis}

Bulk soil samples were used for physical and chemical analyses. Bulk density was measured on volumetric samples following drying at $105^{\circ} \mathrm{C}$. Air-dried and sieved
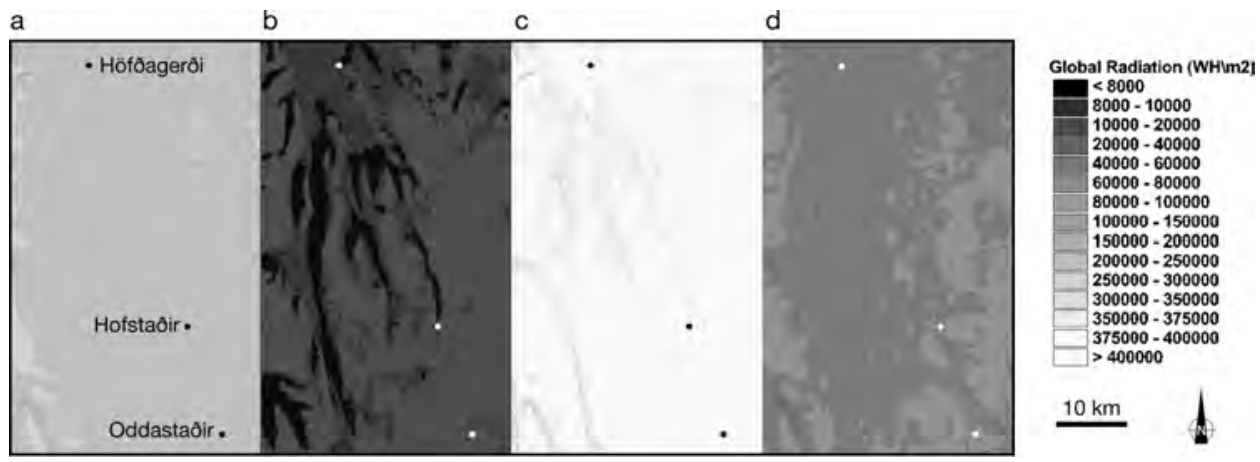

Figure 3. Maps of insolation for Laxá Valley and Mývatn Lake area calculated from latitude of site and regional topography: (a) January-March, (b) April-June, (c) July-September, and (d) October-December. 
subsamples were used for other analyses. Following wet oxidation to remove organic matter, particle size distribution was measured using a Coulter laser-granulometry apparatus. Organic matter was measured by the Walkley-Black method (Klute, 1986), total nitrogen by a modified Kjeldahl method (Nelson \& Sommers, 1982), and total phosphorus by an acid-persulphate digestion and colorimetric measurement (AOAC, 2000). Total carbon was measured by a Dumas technique using total-combustion gas chromatography (AOAC, 2000). Soil thin sections were prepared using standard procedures adapted from the method described by Murphy (1986). Acetone replacement in the liquid phase was followed by impregnation in a polyester resin system applied under vacuum. Following curing, blocks were cut, mounted, ground, and polished to a $30 \mu \mathrm{m}$ thickness on glass slides $(110 \mathrm{~mm} \times 75 \mathrm{~mm} \times 3 \mathrm{~mm})$. Slide thickness was monitored optically and through caliper measurement (Adderley, Simpson, \& Davidson, 2002). Description of the soil thin sections followed the International System (Bullock et al., 1985; Stoops, 2003).

Each of the three soil profiles considered exhibited accumulations of silt loam and fine sandy silt loam with clear, discrete tephra horizons (Figure 4). At Höfð agerði, soil accumulations prior to settlement are reddish brown in color, contrasting with the browns and dark yellowish browns of material accumulated after settlement. Total phosphorus, total nitrogen, and organic matter contents, indicative of organic amendment, show marked increases post settlement (Table III). The highest levels of total phosphorus and total nitrogen are evident immediately above the landnám tephra and below the 1104 tephra, and decline above the 1104 tephra. In thin section (Table IV), features below the landnám tephra are dominated by a brown granular organo-mineral fine material. The landnám tephra itself has been disrupted with mixing of material from the underlying horizon. Soil accumulation associated with settlement is characterized by a dense, dark brown organo-mineral fine material, with increased occurrences of fine organic material and excremental pedofeatures together with very little charcoal. The occurrence of these features declines above the 1104 tephra, paralleling the measured total phosphorus and total nitrogen values.

The field profile at Hofstaðir is characterized by dark brown colors beneath and dark reddish brown above the landnám tephra. Above the landnám tephra, rare fine bone fragments become evident together with common to frequent charcoal occurrences, sometimes organized as thin horizons. Total phosphorus and total nitrogen values are enhanced in the horizons above the landnám tephra, with total phosphorus values being the highest of the three home-field study profiles. While the total phosphorus values are enhanced in the stratigraphy between the landnám tephra and 1104, major increases come between 1104 and 1300, maintained through to 1477 (Table III). In thin section (Table V), soils prior to the landnám and continuing just above the landnám tephra have common pale brown to reddish brown organo-mineral material with few to frequent coarse mineral materials of different types; microstructures are crack and channel and chamber. Fine organic materials are few to frequent and include amorphous black and brown materials. Few reddish amorphous and cryptocrystalline features are evident together with depletion pedofeatures, indicating imperfectly drained conditions. These characteristics 
Höfðagerói

\section{Profile 2}

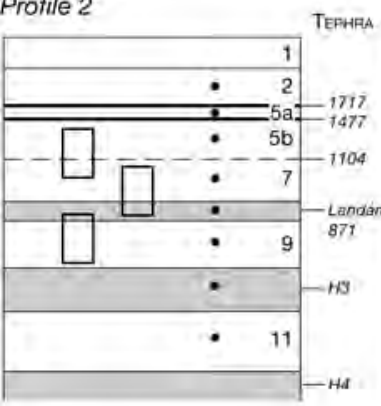

\begin{tabular}{|c|c|}
\hline COLOR & $\begin{array}{l}\text { Texturae } \\
\text { Root mat }\end{array}$ \\
\hline $7.5 Y R 3 / 2$ & Organic silt loam \\
\hline $7.5 Y R \quad 4 / 4$ & Silt loam \\
\hline $7.5 Y R 4 / 4$ & Silt loam \\
\hline $\begin{array}{l}\text { 10YR } 4 / 4 \\
\text { 10YR } 5 / 6\end{array}$ & Silt loam \\
\hline 5YR $4 / 3$ & $\begin{array}{l}\text { Fine sandy } \\
\text { silt loam }\end{array}$ \\
\hline YR $4 / 4$ & Silt loam \\
\hline
\end{tabular}

Silt loam

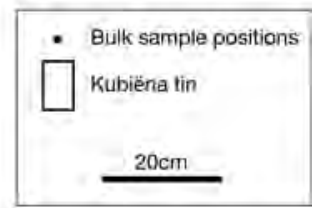

\section{Hofstadir}

Profile $F$

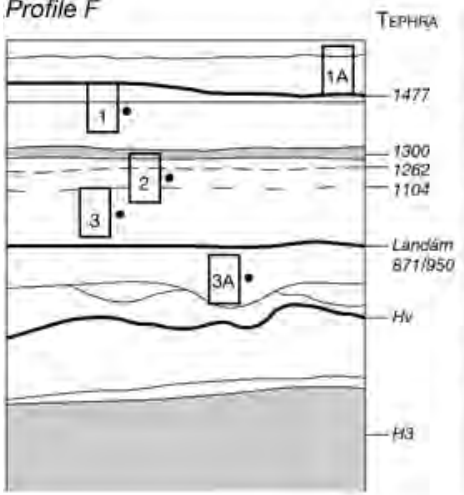

\begin{tabular}{l}
\multicolumn{1}{c}{ Couor } \\
5YR $3 / 3$ \\
2.5 YR $3 / 4$ \\
2.5 YR $3 / 4$ \\
5YR $5 / 6-5 / 4$ \\
7.5 YR $4 / 4$ \\
7.5 YR $3 / 2$ \\
5 YR $3 / 2$ \\
7.5 YR $3 / 2$ \\
7.5 YR $4 / 4$ \\
\end{tabular}
Root mat Organic silt loam Silt loam Sitt loam

Silt loam Silt loam Sitt loam Silt loarn Silt loam Silt loam
Inctusions.

Rare bone

Charcoal horizon

Rare bone

Charcoal horizon

Frequent charcoal
Common charcoal

\section{Oddastaôir}

\section{Profile 3}

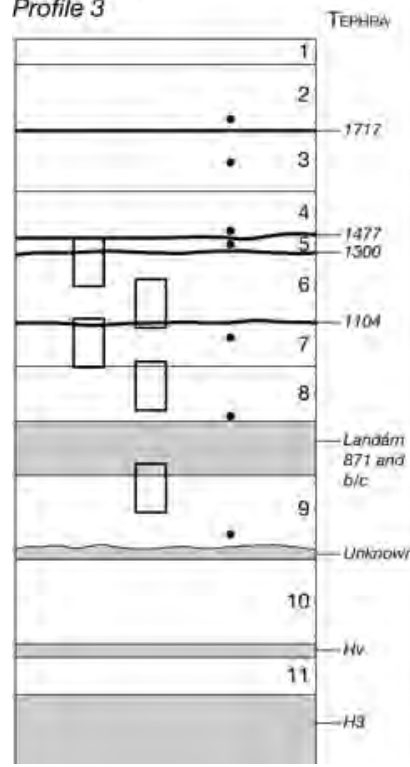

COLOR
10YR $4 / 4$
10YR $4 / 4$
7.5 YR $3 / 2$
7.5 YR $3 / 2$
7.5 YR $3 / 3$
$7.5 Y R 3 / 3$
5 YR $3 / 3$
$5 Y R 3 / 3$
5YR $3 / 4$

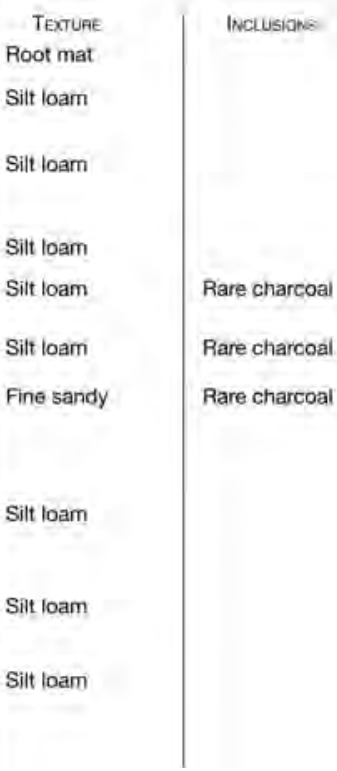

Figure 4. Exposed representative soil profiles from Höfðagerði, Hofstaðir, and Oddastaðir. 


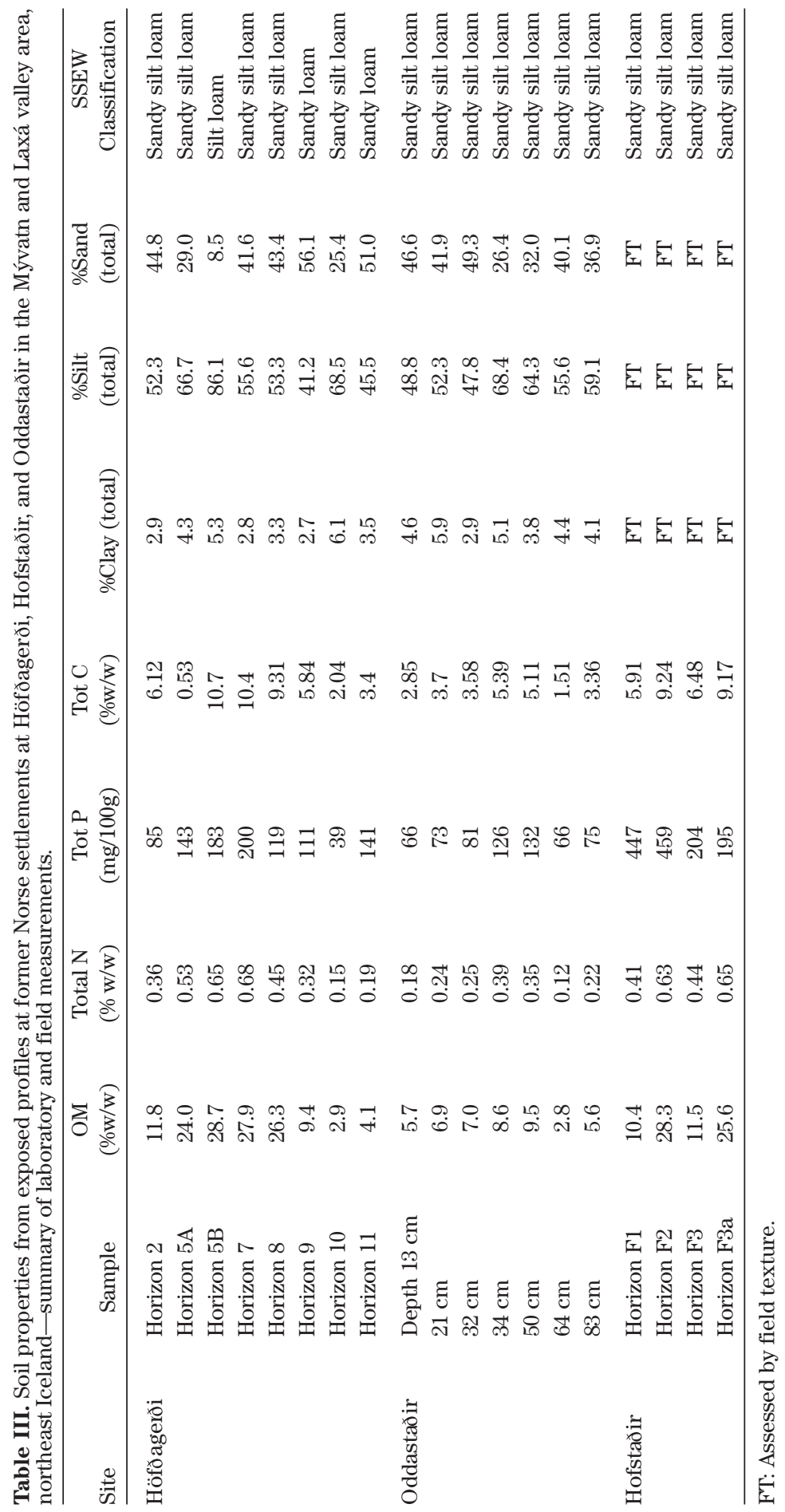




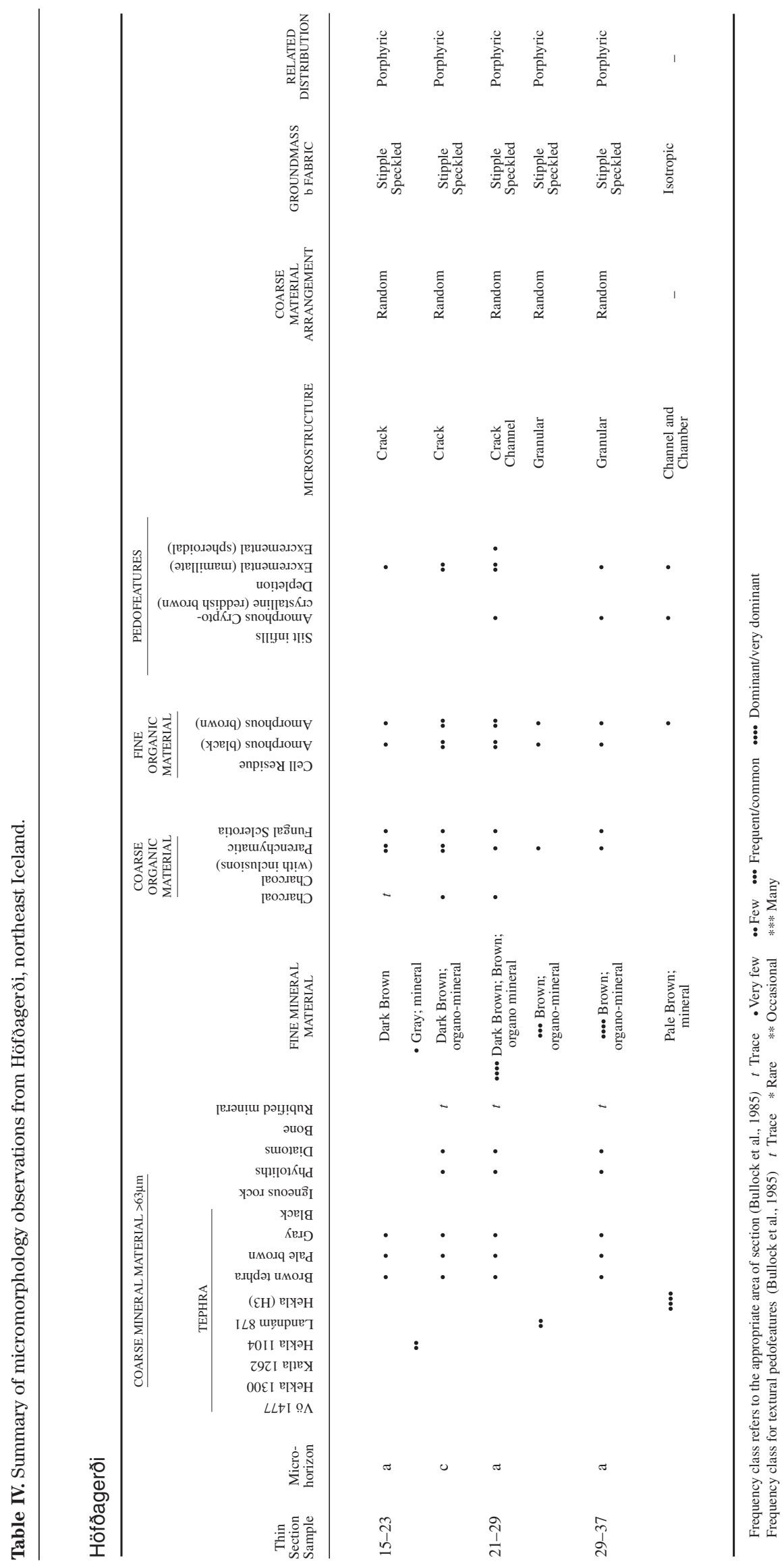




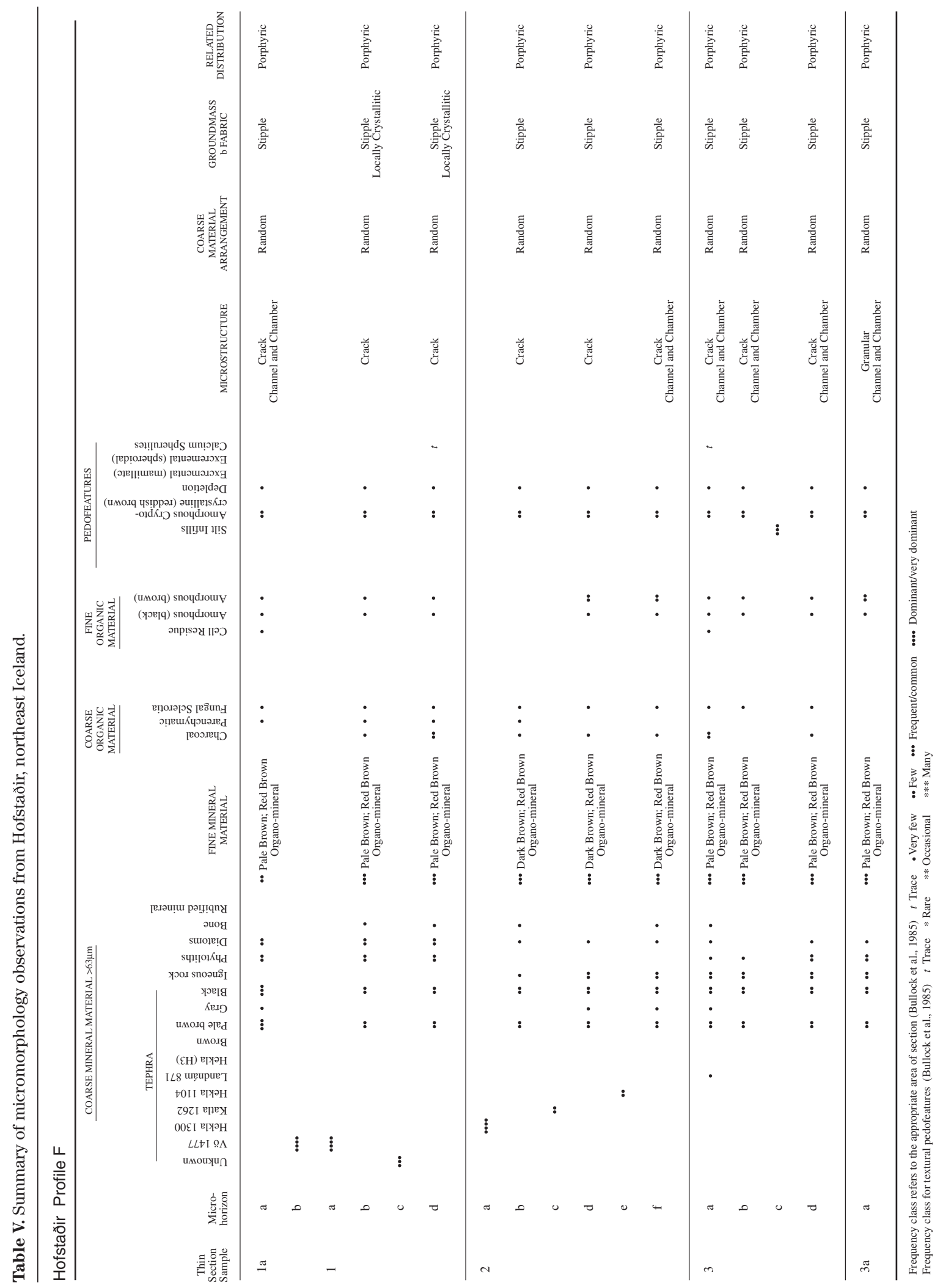




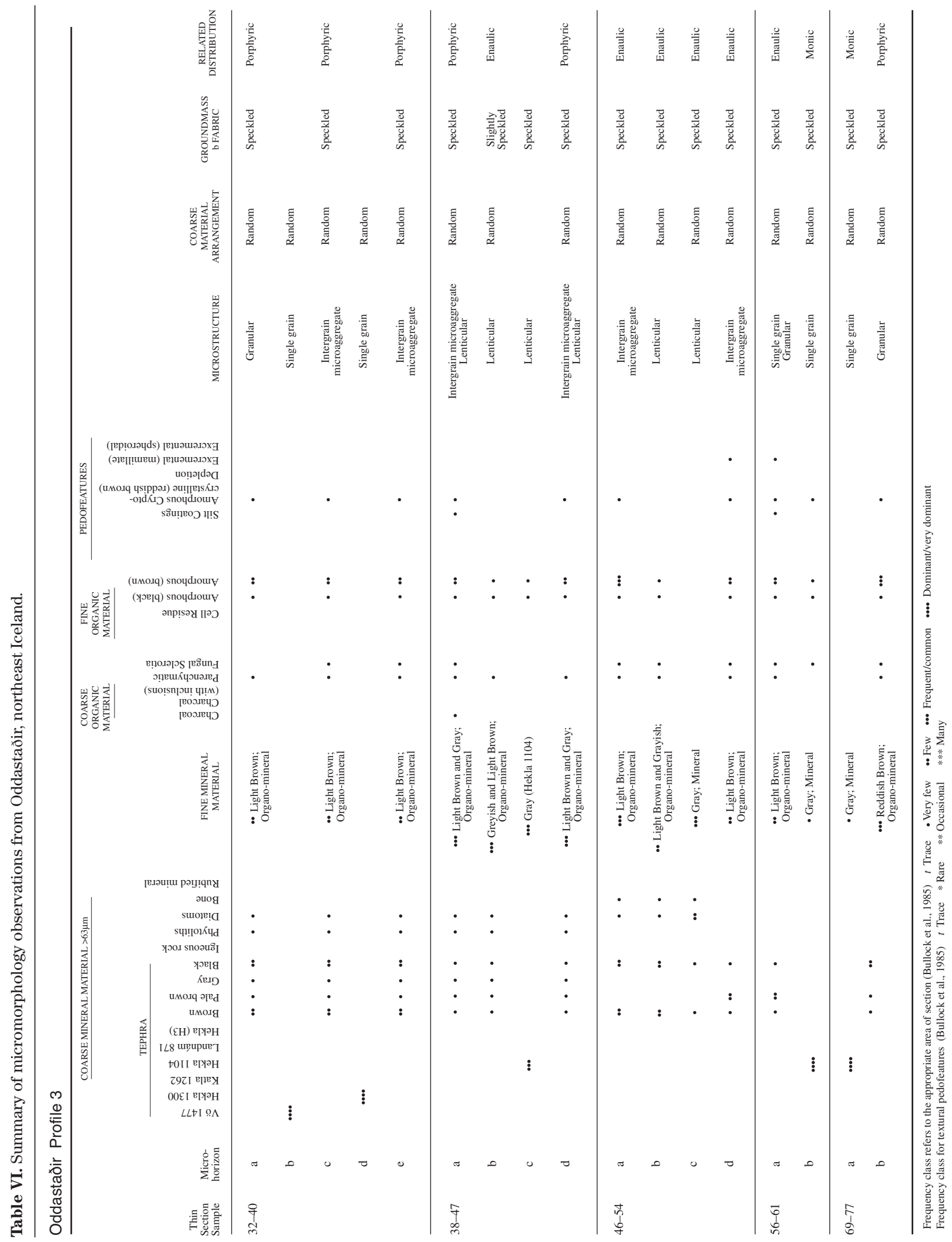


continue immediately above the landnám tephra to a microstratigraphic sequence of contrasting silt and fine sand infills indicative of landscape disturbance (Figure 5); this sequence is also evident in the corresponding thin section from the second profile exposed in the home-field, indicating that disturbance impacted across the area that became the Hofstaðir home-field. Above the silt and fine sand infill sequence, soil accumulation characteristics revert to the micromorphological features observed before and immediately after the landnám tephra, with no evidence of cultural amendment. It is clear that there was an initial impact followed by a hiatus, after which cultural amendment of the soil began. Micromorphological features indicating substantial cultural amendments of the imperfectly drained and organic silt loam soil are evident in the sedimentary sequence before 1104 and through to the 1477 tephra. Amendments include domestic waste, evidenced as bone fragments (Figure 6), fuel residues including woods (charcoal and crystallitic fine mineral material), peats (rubified fragments; Figure 7), and animal manures (calcium spherulites, very rare and degraded but partially preserved beside bone fragments). These features vary in occurrence and are at their most frequent between the 1104 and 1300 tephras. Above the 1477 tephra, indicators of cultural amendment are absent, indicating a curtailing of attempts to maintain home-field fertility, a change in home-field focus or, in light of the reduced impact on upland grazing areas (Thomson \& Simpson, 2007), there may have been a temporary abandonment of the site.

Of the three home-field profiles considered (Figure 4), soil accumulation is at its greatest at Oddastaðir, with reddish brown pre-landnám accumulations contrasting with very dark grayish browns of the post-landnám sequences, within which are embedded rare occurrences of charcoal. These cultural inclusions are reflected in the total phosphorus, total nitrogen, and organic matter values, which, although having the lowest levels of the three home-field profiles, increase above the landnám tephra, are maintained between 1104 and 1300, but decline markedly above this tephra (Table III). In thin section (Table VI), a fine organo-mineral granular material is dominant, with frequent brown amorphous fine organic materials below the landnám tephra and continuing just above this tephra horizon. A sharp boundary is evident between this lower micro-horizon and a complex repeating micro-horizon sequence of silts and fine sands, fine gray mineral material, and brown organo-mineral fine material. Fine organic materials are few, and microstructures are intergrain microaggregate and lenticular. This sequence of accumulation continues to the 1104 tephra. Above the 1104 tephra and through to the 1300 tephra, a consistent range of coarse mineral material is evident, together with mixed brown and gray fine mineral material with intergrain microaggregate and lenticular microstructures maintained. Very little charcoal is evident in this part of the stratigraphy; in profile 4, twenty meters downslope from profile 3 , very few fine bone fragments are found in the equivalent part of the stratigraphic sequence. Above the 1300 tephra, coarse mineral material and light brown fine mineral materials organized as porphyric granular and intergrain microaggregate microstructures predominate. 

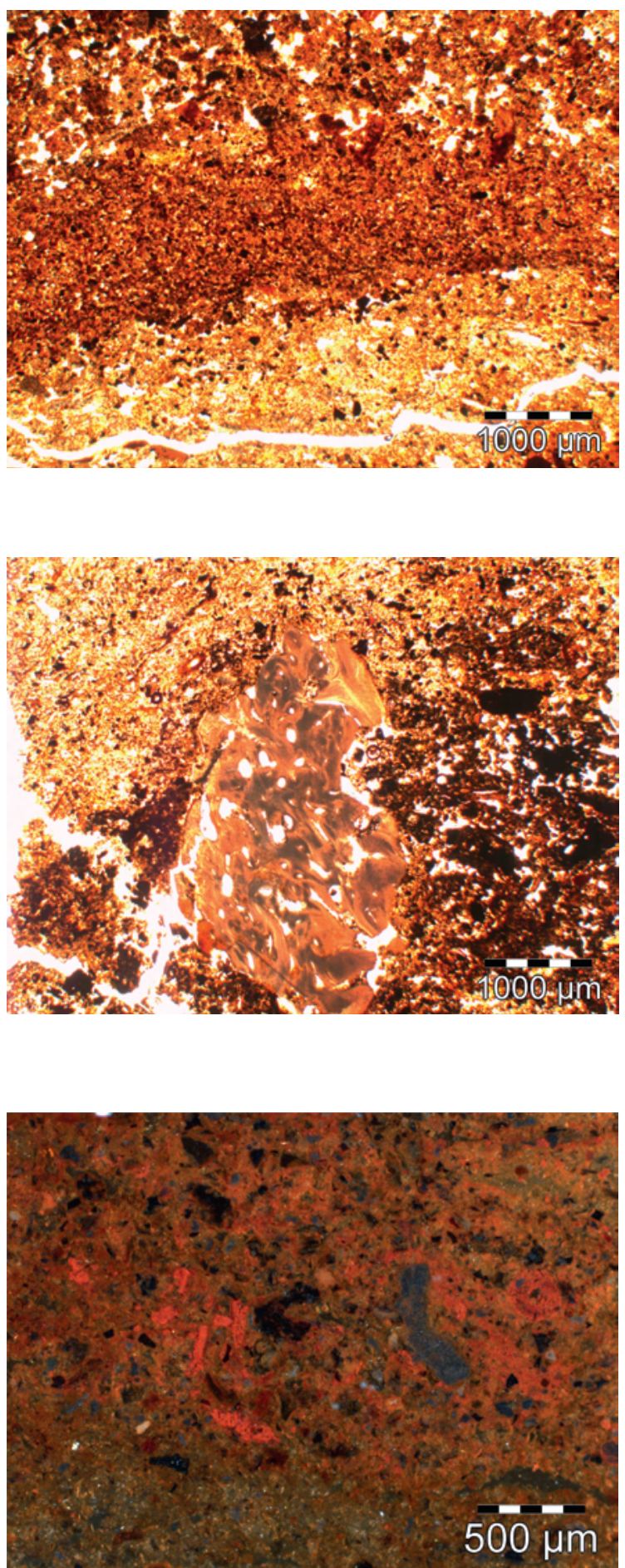

Figure 5. Linear silt and fine sand accumulations between landnám and 1104 tephra, Hofstaðir profile F4 sample 3, micro-horizon c. Indicative of landscape disturbance. Plane-polarized illumination.

Figure 6. Bone and domestic debris located above silt and fine sand accumulations and below 1104 tephra, Hofstaðir profile F4, sample 3, microhorizon a. Indicative of soil amendment. Plane-polarized illumination.
Figure 7. Rubified peat fuel residues with fine charcoal. Located above silt and fine sand accumulations and below 1104 tephra, Hofstaðir profile F4, sample 3, micro-horizon a. Indicative of soil amendment. Oblique incident illumination. 


\section{MODELING HOME-FIELD PRODUCTIVITY}

\subsection{Model Initialization}

In order to examine the effect of differences in microclimate among the three field sites, productivity of the home-field areas in production of hay has been modeled following the method established in earlier studies (Adderley et al., 2000; Simpson et al., 2002; Adderley \& Simpson, 2005). The well-verified CENTURY agroecosystem model (Parton et al., 1987; Metherell et al., 1993) is based on turnover of soil organic carbon. The model runs on a monthly time step. Requirements for the model are temperature and precipitation data, which are related to evopotranspiration and soil drainage, above- and below- ground decomposition of organic materials, and plant growth (Figure 8). Inputs of carbon to the agroecosystem model are through plant growth and senescence, and through organic manure inputs. Where there is no loss through erosion, carbon that is considered removed from the turnover model is that lost by soil microbial processes and through plant material removed by aftermath grazing and hay harvesting.

The model has been initialized after considering the available paleoecological evidence for the vegetation (Dugmore et al., 2005) and with starting values of soil nutrient concentrations, based on the measured values obtained from samples below the landnám tephra and considered relatively undisturbed at each home-field site (Adderley \& Simpson, 2005; Adderley et al., 2002; Kelly et al., 1997). The carbon pools in the model were initialized over a nominal 2000 years assuming that the prelandnám land cover in the Laxá Valley and Mývatn region was a grass and woody shrub mixture. The contribution of the shrub components prior to the creation of the home-field is based on observations of similar vegetation in the U.K. (Ovington \& Madgwick, 1959) and Greenland (Elkington \& Jones, 1974). The dry matter and carbon and nitrogen composition of the removed plant material is based on typical

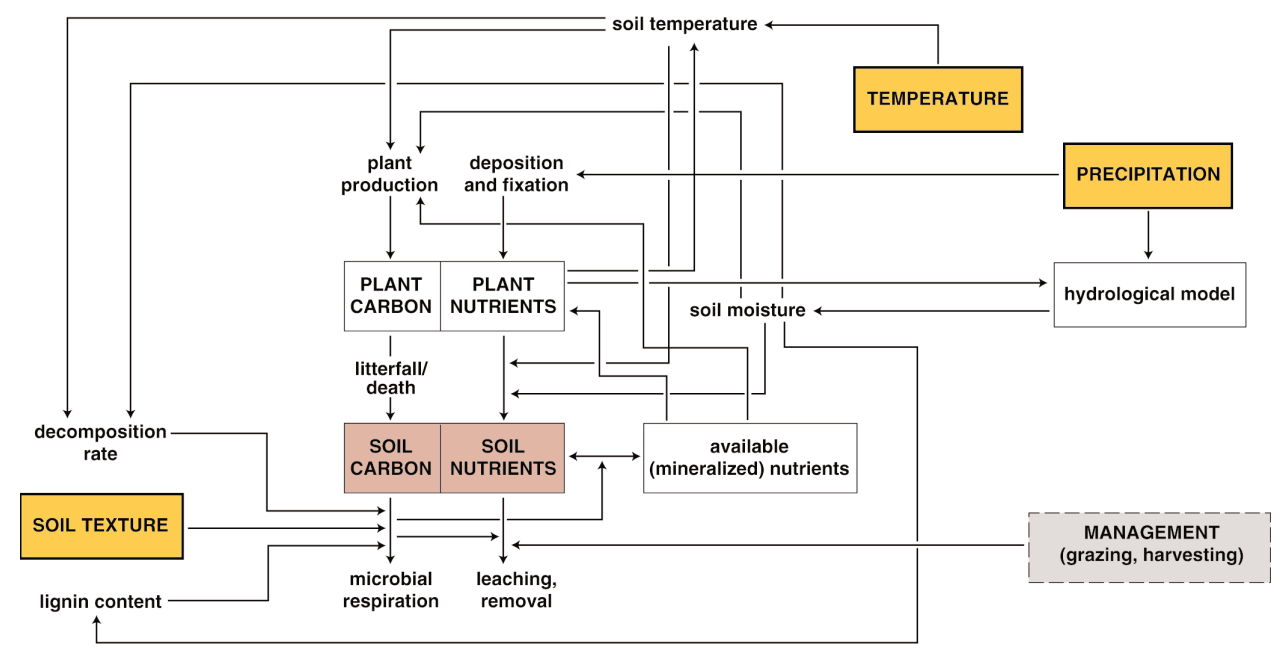

Figure 8. Schematic of CENTURY model pools and fluxes. Adapted from Körschens (1998). 
native grasses. These and grass-growth parameters were based on previous experimental studies in Iceland (Thorvaldsson, Haahr, and Høegh, 2000; Thorvaldsson \& Martin, 2004) and from long-term field trials in the British Isles (Shiel \& Hopkins, 1991). These allow the maximum annual hay yield before storm, storage, and other losses to be calculated.

\subsection{Scenarios Modeled}

Application of this modeling paradigm with monthly time steps to historical and archaeological contexts places high demands on the data available but offers a key advantage in that the integration of multiple data sources potentially minimizes the model's sensitivity to individual factors. The sensitivity of the model to the climate factors has been tested individually. The home-field areas at each of the three farm locations have been modeled for hay production. This includes a unique climate reconstruction for each site and the different soil properties for each site; the timing of management practices - for example, hay harvest date-through the farming year is considered to be consistent across all locations. Both the hay yields and the accumulation of soil organic matter have been considered. The latter has been previously demonstrated (Adderley \& Simpson, 2005) to provide a buffer for the Norse farmer against year-to-year climate changes.

Four sets of circumstances have been considered: First, the chronologies of soil management activities examined by soil micromorphology (above) are incorporated into the model. Using these micromorphology and tephra chronology data, clear differences in manure inputs are found, with periods of different relative manuring rates as well as periods with no observed input. The baseline, or "normal," input of carbon from manure has been considered to be a rate of $100 \mathrm{~g} \mathrm{C} \mathrm{m}^{-2}$ per application. For periods of high manure input, an input of $200 \mathrm{~g} \mathrm{C} \mathrm{m}^{-2}$ per application-that is, "double" input-has been modeled. The value of $100 \mathrm{~g} \mathrm{C} \mathrm{m}^{-2}$ per application mirrors practices seen elsewhere in Iceland (Simpson et al., 2002) but is a relatively low input compared to the sustainability of traditional Shetland farming practices (Adderley et al., 2000). On this basis, Höfðagerði received "double" inputs for the period A.D. 870-1104, followed by "normal" inputs from A.D. 1104 onward. The home-field at Hofstaðir received "normal" input from A.D. 870 to 1104, "double" input for A.D. 1104-1477, and "normal" input post A.D. 1477. Oddastaðir, receiving the lowest overall input, appears to have "normal" input for A.D. 870-1300 and no input post A.D. 1300.

Second, scenarios of continuous uniform inputs are considered. The effect of maintaining continuous annual manure inputs has been compared between a "normal" manuring application ( $100 \mathrm{~g} \mathrm{C} \mathrm{m}^{-2}$ per application) and a "double" rate of annual manuring (200 $\mathrm{g} \mathrm{C} \mathrm{m}^{-2}$ per application).

Third, using these "normal" and "double" scenarios, the effect of grazing in the home-field has been considered. Scenarios with no grazing whatsoever are compared to a grazing scenario in which grazing for one month before leaving the grass for the hay crop and grazing in the aftermath of mowing for two months are incorporated in the model. 
Fourth, sensitivity to small climate shifts relative to the inherited soil characteristics has been considered. This has been undertaken by considering a set of scenarios modeled with all management and exogenous parameters fixed, including climate (fixed as the Hofstaðir reconstruction) across all sites, thereby examining the differences in inherited soil site characteristics alone.

\section{MODELING RESULTS}

The CENTURY agroecosystem model considers both natural and land management factors. In particular, the model outputs allow contrasts between the inherent soil and climate conditions at each home-field site to be compared not only with other sites, but also in regard to different land management scenarios.

The modeled outputs that consider differences in soil management for different periods are shown in Figure 9. The Höfðagerði and Hofstaðir sites both show consistently higher yields than Oddastaðir, once established. This contrast extends throughout the Norse period. In the period after landnám, both Höfðagerði and Hofstaðir show rapid rises (Figures 9a, 9b) in yield from the commencement of farming. The values of hay yield modeled for each site reach plateaux in yield after ca. 75 years. The modeled results from Hofstaðir reveal erratic year-to-year hay yields compared to Höfðagerði. All three sites have relatively low hay yields compared to other locations that have been considered in the North Atlantic (Adderley \& Simpson, 2005). In contrast to Höfðagerði and Hofstaðir, the effect of manure inputs on hay yield at Oddastaðir (Figure 9c) shows a period of long-term increase for ca. 150 years before reaching a similar plateau. This suggests that the benefits at this site, in terms of hay production, required prolonged manure input and consequently a reliable source of manure. Across all sites, where changes in manure inputs are observed in the soils-based evidence, these are apparent in the modeled outputs. As would be expected, lower manure inputs lead to lower yields and vice versa. However, the rate at which such changes occur (i.e., how the modeled yield changes when manure application rates change or cease) is markedly different for each site. Hofstaðir appears to respond most rapidly to changes in input, whereas change at Oddastaðir occurs over several decades. These modeled results may be compared with different scenarios to consider the relative impacts of different possible management actions by the Norse farmer.

The results of continuous manure inputs with grazing of the aftermath on a homefield are shown in Figure 10. Here consistent differences in modeled hay yield between sites are evident in both the "normal" (Figure 10a) and "double" (Figure 10b) situations. With "normal" manuring inputs, Höfðagerði has the greatest yield (maximum $0.92 \mathrm{t} \mathrm{ha}^{-1} \mathrm{a}^{-1}$ ) of the three sites. For all three sites there is a period of approximately 150-200 years of increasing long-term mean yield before a plateau (as defined by Reilly \& Fuglie, 1998) is reached. The "double" manure scenario (Figure 10b) shows a markedly higher initial yield relative to the "normal" scenario (Figure 10a) before declining slightly to reach a plateau after $75-100$ years. Once this plateau is reached, the maximum yields are very similar to the "normal" scenario. These modeled scenarios of continuous uniform input reveal that given sufficient inputs the Höfðagerði 

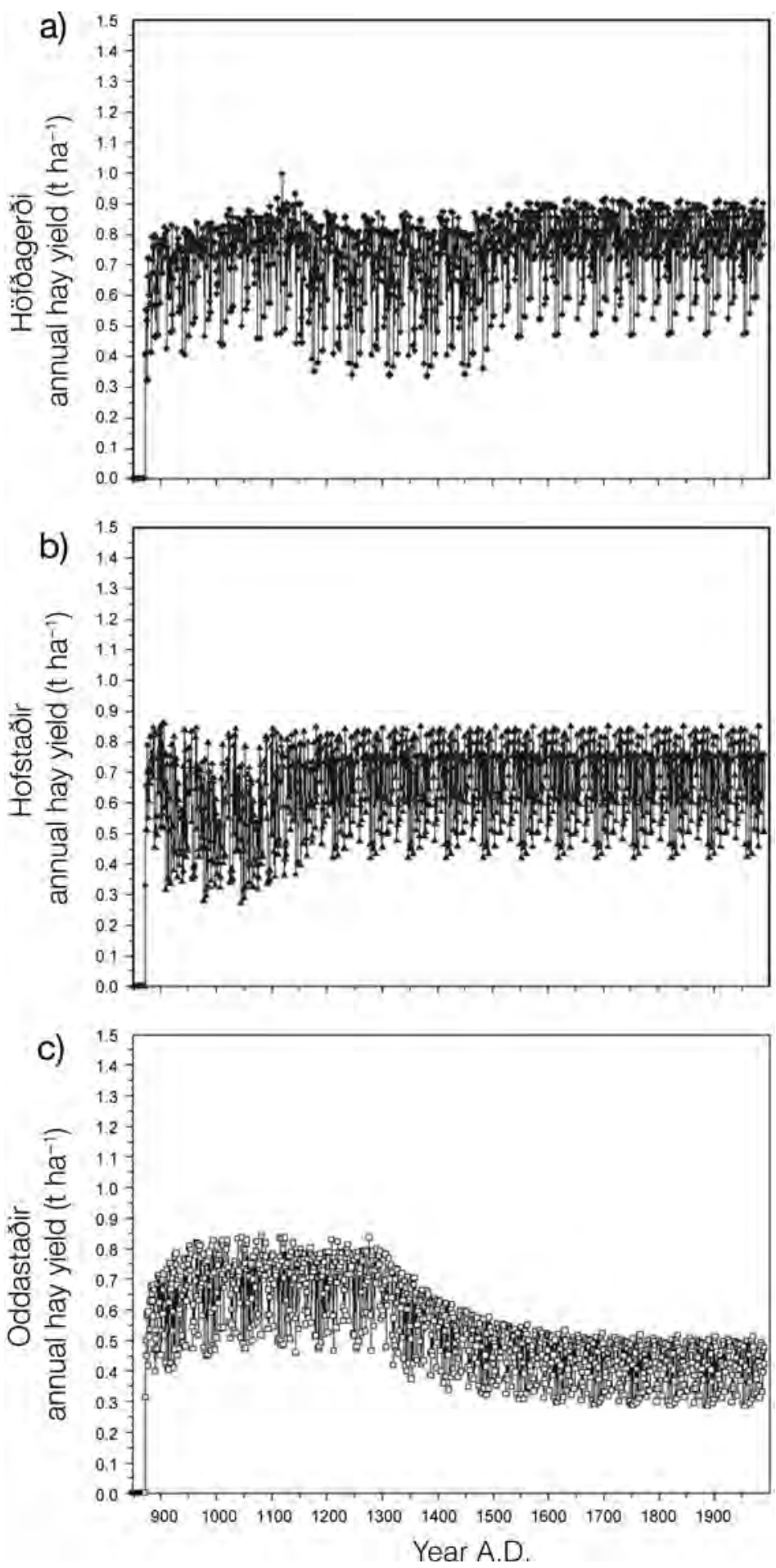

Figure 9. Results of CENTURY modeling, incorporating soils-based evidence of changes in land management: (a) Höfðagerði, (b) Hofstaðir, and (c) Oddastaðir. 

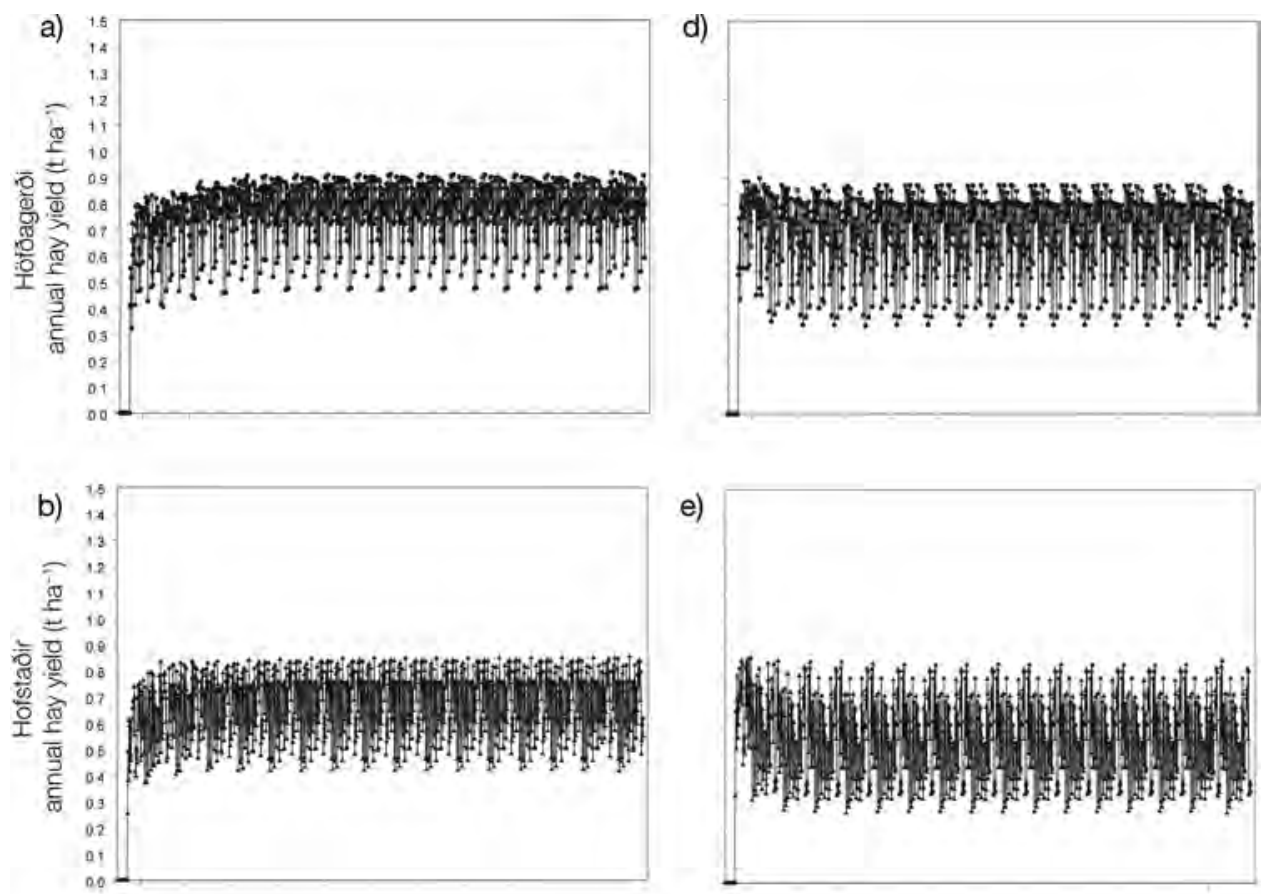

e)
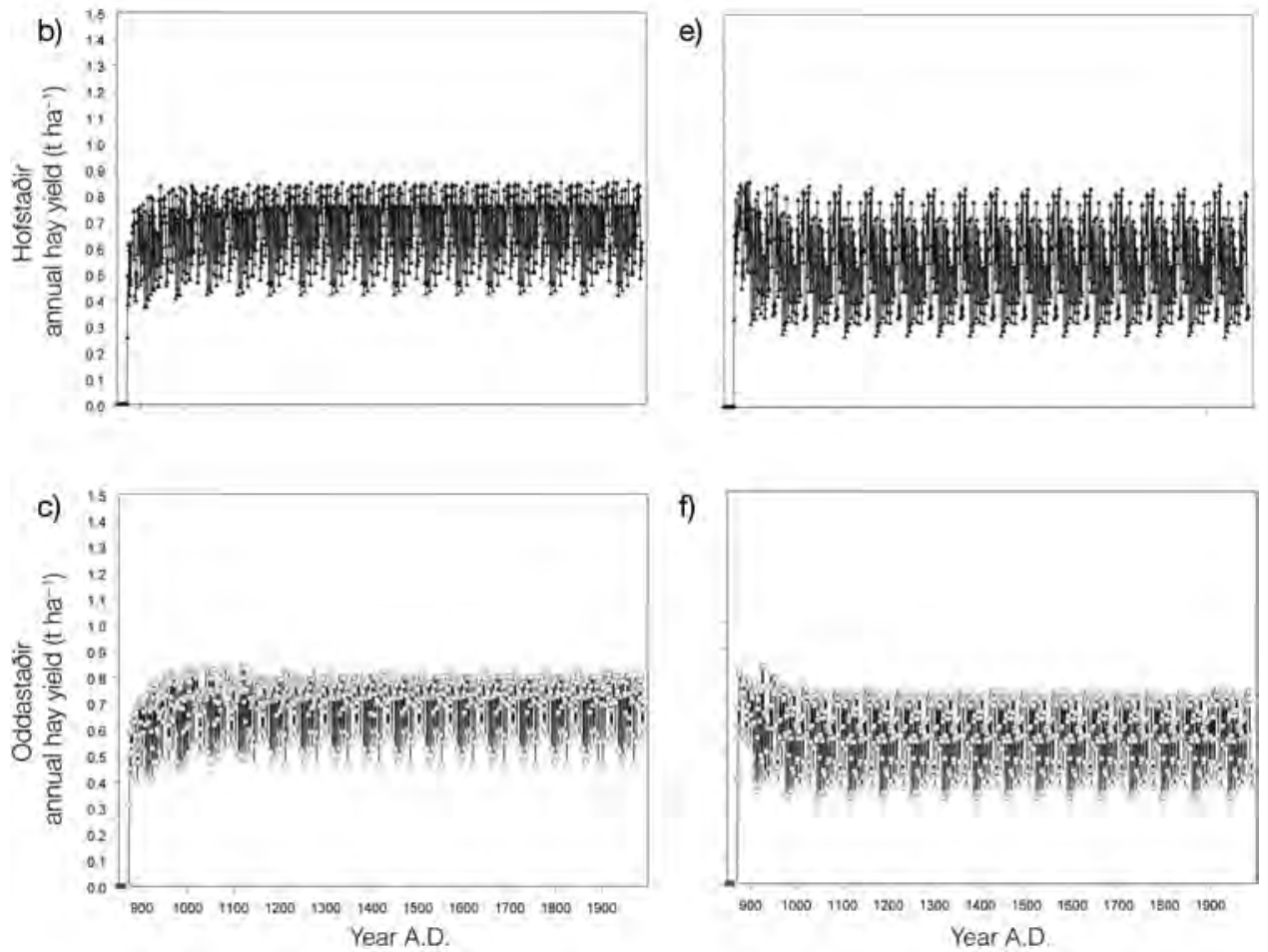

Figure 10. Effect of manure management. Results of CENTURY modeling-hay production on home-field areas. Scenario of "normal" level of manuring combined with grazing of the aftermath for (a) Höfðagerði, (b) Hofstaðir, and (c) Oddastaðir. Scenario of "double" level of manuring combined with grazing of the aftermath for (d) Höfðagerði, (e) Hofstaðir, and (f) Oddastaðir.

site is the most productive overall, with Oddastaðir slightly more productive than Hofstaðir.

The effect of aftermath grazing can be seen by considering the difference between grazing scenarios where this factor is and is not removed. The scenario of "normal" manuring but no grazing at each site (Figure 11a), and similarly "double" manuring 
with no grazing (Figure 11b), show increased maximum yields relative to the scenarios with grazing (Figures 10a, 10b) for all sites. Both of these no-grazing scenarios show yields reaching plateaux within 75 years of home-field establishment.

The sensitivity of the model outputs to changes in rainfall inputs has been tested, and for each site, regardless of any increase in annual precipitation input, shows $<2 \%$ maximum increase in total hay output. In Figure 12, the climate reconstruction for Hofstaðir has been used for all three sites, so the small differences seen in this figure represent the extent to which the inherent differences in soil characteristics affect yield. This applies particularly to drainage and the water-holding capacity in the upper $20 \mathrm{~cm}$ of the soil profile. There is again a small but consistent difference between sites, with Höfðagerði having slightly higher yields.

\section{DISCUSSION}

This modeling study has shown clearly that there are many confounding factors related to the productivity of the Norse home-fields of the Laxá Valley and Mývatn region of northeast Iceland. It is also evident that the maximum levels of productivity, regardless of the management strategy adopted, are generally no better than subsistence, with little possibility for carrying over fodder material year-to-year to create a storage buffer (Eggertsson, 1998; Bjarnason, 1912) for years with poor yield. This suggests an imperative to develop an understanding of different possible land management strategies and their relationship to past climatic variations.

All the scenarios modeled have considered the same dates for manuring, hay harvesting, and grazing. In respect to climate and site differences, the actual hay yield the Norse farmer obtained, rather than the maximum hay yield as sought through the modeling, will have been lower due to loss due to storms and poor drying conditions for hay-making. For all the scenarios modeled (Figures 9-12), short-term (i.e., yearto-year) variabilities in hay yield are common to all three sites and may be explained by region-wide climatic fluctuations. Especially important appear to be prolonged cold periods in either spring or autumn or both, all of which limit the plant growth period. In the more extreme conditions of Greenland, it has been demonstrated that responses such as irrigation of the home-field were required by the Norse settlers to promote grass growth due to summer drought following cold winter periods (Adderley \& Simpson, 2006). With the model outputs appearing insensitive to increases in precipitation, for the three sites considered in the Laxá Valley and Mývatn region, water availability does not appear to be a limiting factor in grassland productivity.

It is when long-term trends are considered that local level inter-site differences become most apparent. At this local spatial level there are clear differences in the microclimates found at each site (Table III). These differences are predominantly related to elevation and coastal effects (Figure 2). The incoming solar radiation (insolation) at each site and the resultant heat flux (McCune \& Keon, 2002) will influence temperatures and consequently plant growing conditions. However, while insolation is one of several factors that influence temperatures, the effect will vary throughout the year. The differences in insolation are most pronounced (Figure 3) during the winter months (up to $25 \%$ difference between sites in February), when 

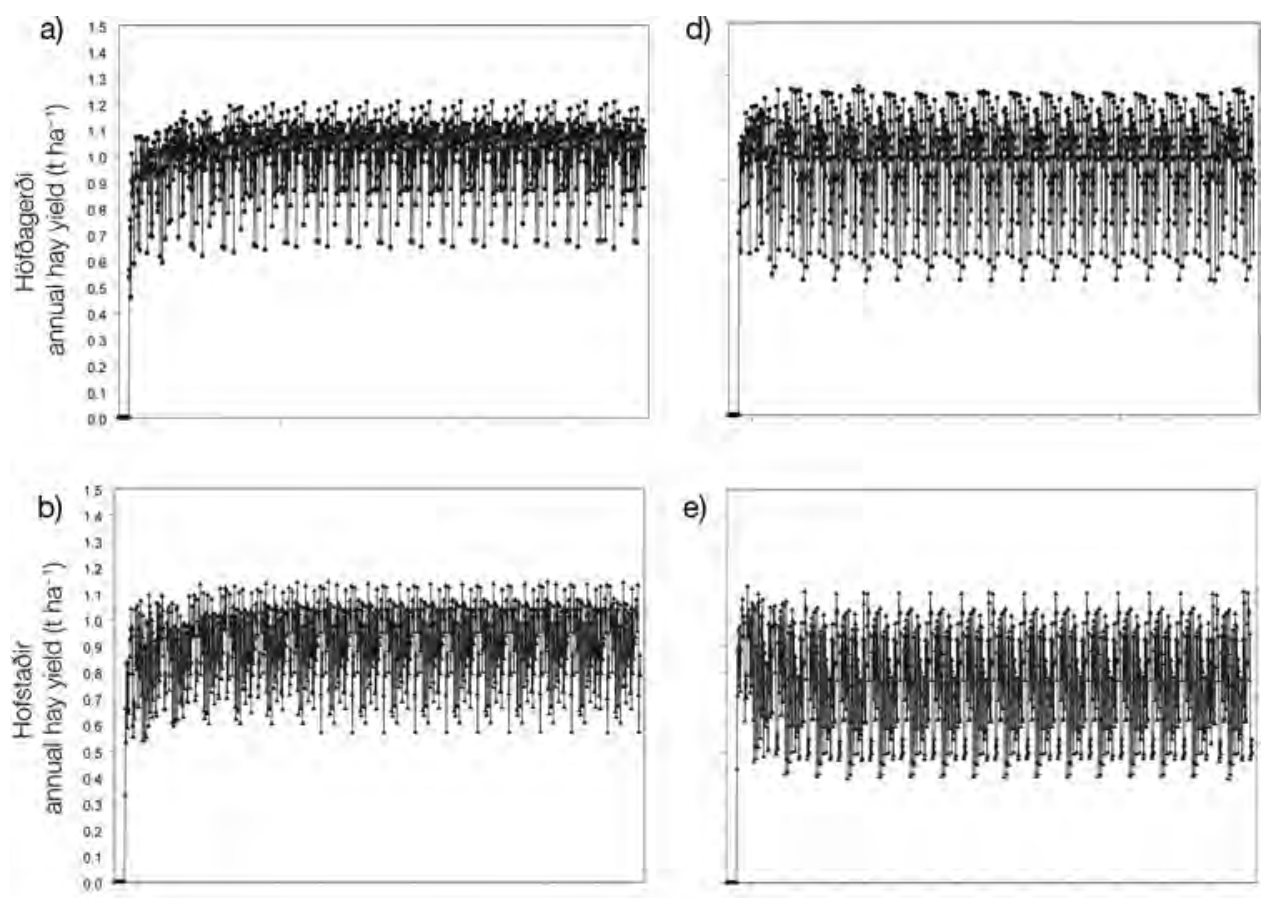

e)
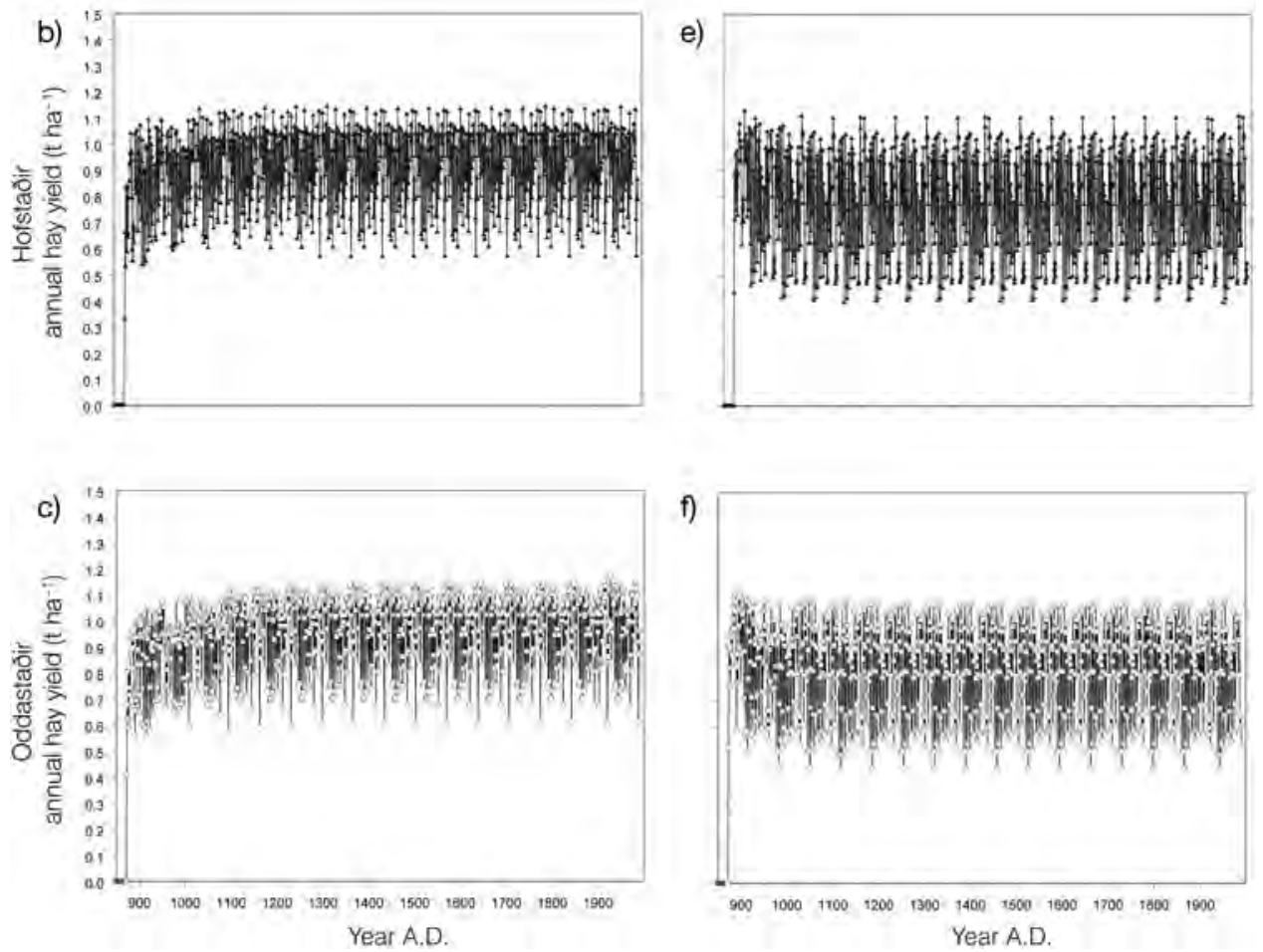

Figure 11. Effect of home-field grazing management. Results of CENTURY modeling — hay production on home-field areas. Scenario of "normal" level of manuring combined with no grazing of the aftermath for (a) Höfðagerði, (b) Hofstaðir, and (c) Oddastaðir. Scenario of "double" level of manuring combined with no grazing of the aftermath for (d) Höfðagerði, (e) Hofstaðir, and (f) Oddastaðir.

the effect of latitude determines the insolation. While there is a small effect due to the topography of the surrounding landscape, during the growing season for the Icelandic hay crop (ca. April-August) the difference in insolation between sites is much reduced (4-8\%). Hence, while undoubtedly a factor in determining local site temperatures, it appears that differences in insolation alone do not influence the relative success of hay production at these settlement sites. 

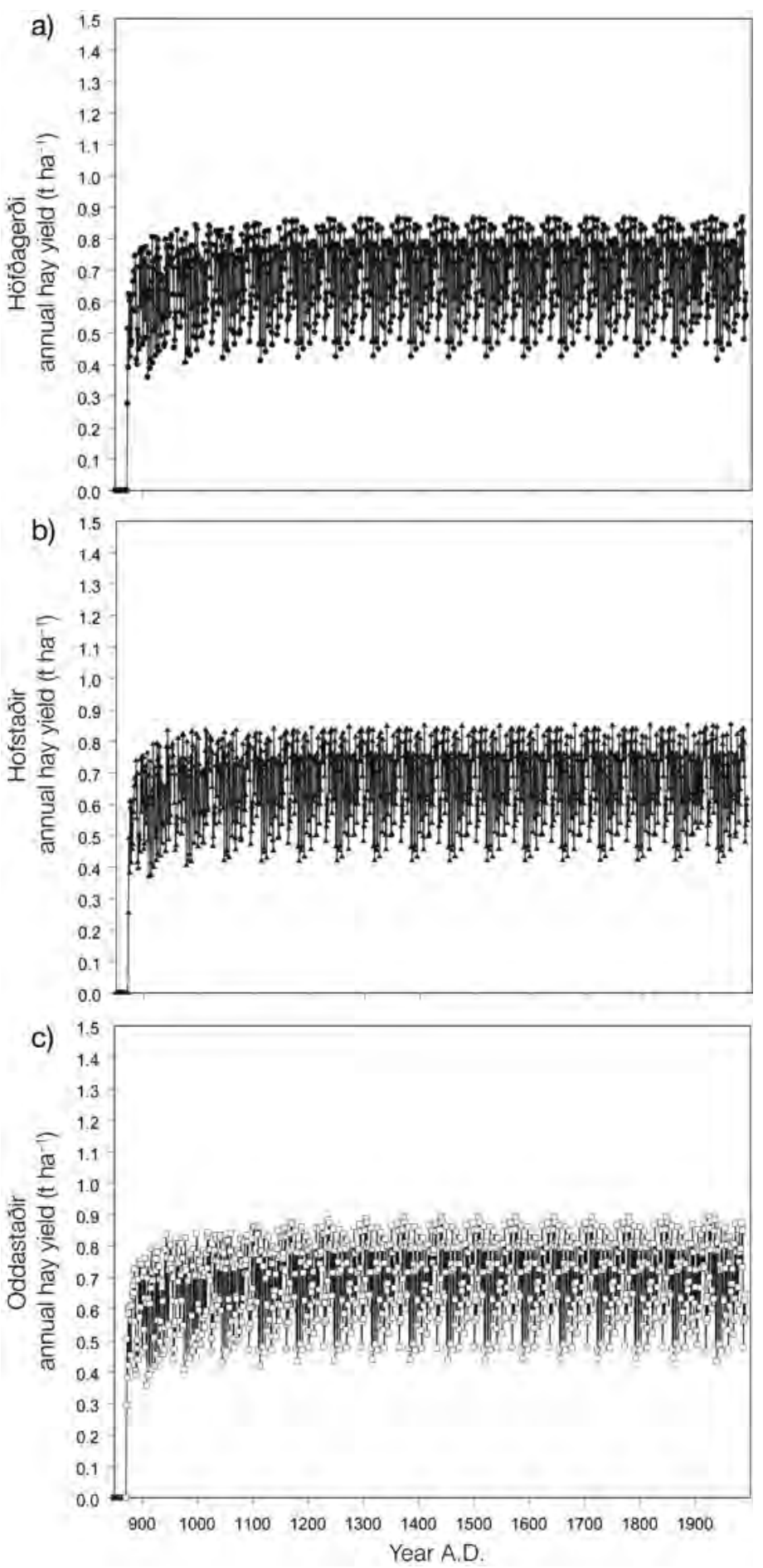

Figure 12. Effect of inherent site properties. Results of CENTURY modeling using fixed weather factor with all other factors fixed, with "normal" manuring and aftermath grazing at each site. 
The effects of the different climate conditions found at each site are apparent in the modeling outputs. While temperature and precipitation are confounded in the model, the variation is due mostly to the relationship between air temperature and plant growth. Considering the contrast between the outputs using individual climate reconstructions (Figure 10a) and the outputs produced with a single climate reconstruction for all three sites (Figure 12) with all other parameters fixed, this reveals clear differences in yield. These differences in yield between sites can be attributed to the variation in the local climate along the Laxá Valley toposequence (Figure 2). The results with the fixed climate reconstruction (Figure 12) also reveal that there is an effect due to differences in the inherent soil properties at each site, with the Höfðagerði site displaying the most favorable conditions.

The contrast between the modeled outputs that incorporate changes in manure input (Figure 9), as compared to fixed continuous manure inputs (Figures 10, 11), reveals that maintaining the intensity of land management was fundamental to maintaining hay yield. This is especially the case at Hofstaðir (Figure 9b), which is both the most sensitive to change and shows erratic yields when manure inputs are low. These results demonstrate the extent to which a single exogenous or site-related factor can be considered limiting to production, and emphasize the need to understand the issues related to different land management strategies of the Norse farmers and to site selection by the first landnám settlers. The influence of landscape on the chosen locations of Viking and Norse settlements is subject to increasing discussion and analysis (e.g., Gansum, Jerpåsen, \& Keller, 1997). In this instance, the differences in home-field productivity contrast with the perceived relative status of each settlement. This particularly concerns Hofstaðir, an undoubtedly high-status settlement but with what appears to be the least inherently productive home-field upon settlement (Figure 10a). This suggests that other strategic elements played a role in decisions relating to initial site settlement rather than the initial yield per unit area from the home-field and that different land management evolved at each sitein the case of Hofstaðir, rapidly and successfully sustaining agriculture over the last millennium (Figure 9b).

When the role of land management is considered beyond the initial settlement period, it is clear that the hay yields reach a plateau at each site. If the "normal" manuring scenario is considered and the soil conditions are examined, then the slightly slower decay rates at Oddastaðir show an effect in the total soil carbon concentration (Figure 13). This suggests that sustained management over the first three centuries of settlement could produce a home-field area that offered a nutrient buffer against adverse growing years. This has been demonstrated in Faroese contexts as potentially mitigating some of the year-to-year climatic variation (Adderley \& Simpson, 2006). At Höfðagerði, conversely, after the initial settlement period, the total soil carbon concentration declines slightly (Figure 13), suggesting that the buffering effect of manuring was less pronounced. These contrasts highlight the fact that different responses to changing environmental conditions, both shortand long-term, would have been required by the Norse farmer to successfully sustain production. 


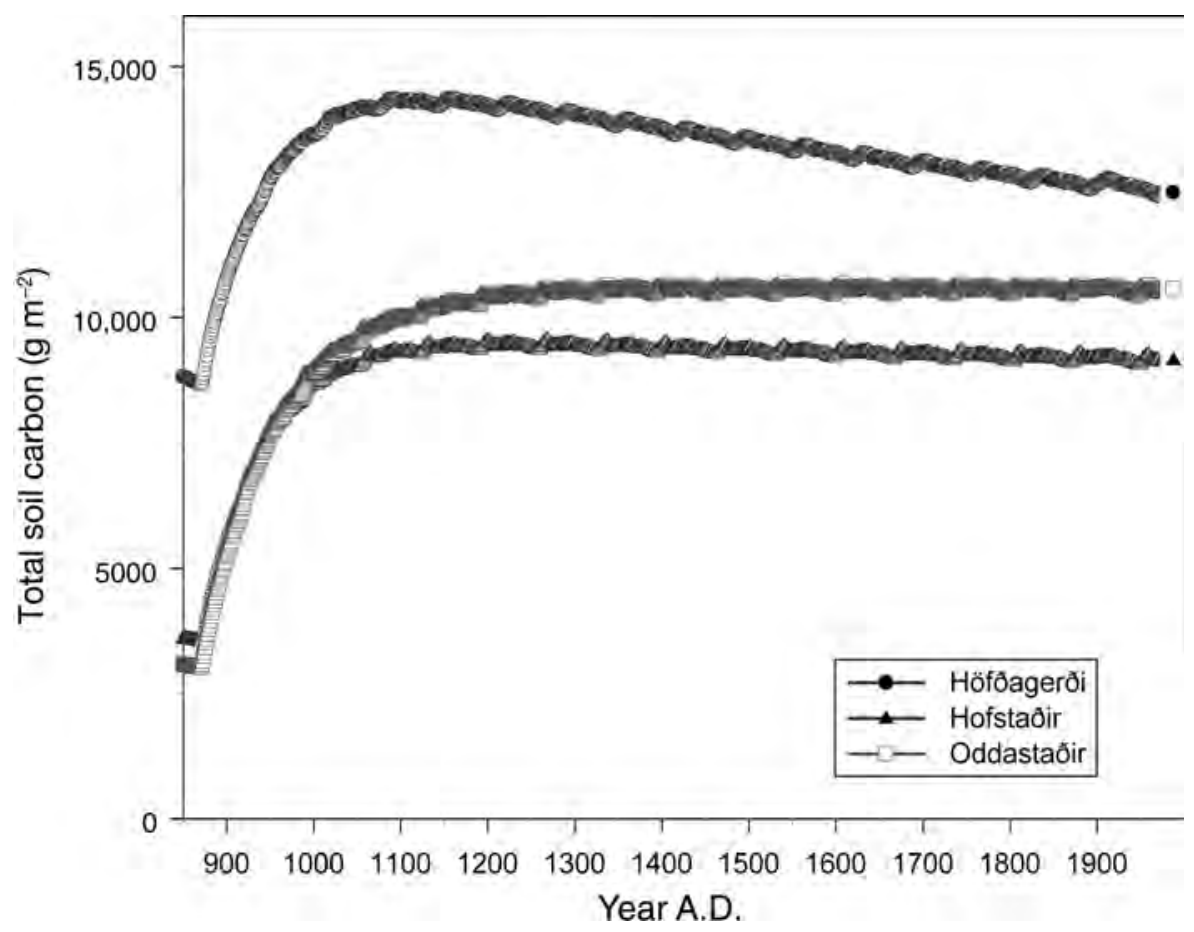

Figure 13. Changes in total soil carbon concentration. Results of CENTURY modeling (scenario as in Figure $10 \mathrm{a}-\mathrm{c}$ ).

\section{CONCLUSIONS}

The production of hay for feeding livestock over the winter was a key component in the sustainable settlement of Iceland during and beyond the Norse landnám. Modeling nutrient turnover in an agroecosystem allows archaeological understanding of past land management to be considered for different scenarios. From these modeling scenarios it is clear that both inherent differences in soil properties as well as local differences in climate influence hay yield across the sites considered in the Laxá Valley and Mývatn area. Despite the sites having different societal status in Norse times, the home-field hay yields are all at a subsistence level. Furthermore, regardless of any changes in management input through, for example, extra manuring, yields remain at subsistence level. The results suggest that the Norse farmer had limited options to increase home-field productivity above subsistence level in this region of Iceland. Providing sufficient resource input could be maintained, the longterm sustainability of this production could be positively influenced by changes in land management practices. These outcomes, however, require long-term commitment in terms of practice and resource. 
The authors gratefully acknowledge the financial support of the Leverhulme Trust, Landscapes circumlandnám Programme, and the Fornleifastofnun Íslands. From the Veðurstofa Íslands, the Icelandic meteorological service, Elín Björk Jónasdóttir kindly assisted the collation of unpublished climate data. From the University of Stirling, School of Biological and Environmental Sciences, Jennifer Brown assisted the GIS analysis, George MacLeod manufactured the soil thin sections, and Bill Jamieson produced the maps and figures.

\section{REFERENCES}

Adderley, W.P., \& Simpson, I.A. (2005). Early-Norse home-field productivity in the Faroe Islands. Human Ecology, 33, 711-736.

Adderley, W.P., \& Simpson, I.A. (2006). Soils and paleo-climate based evidence for irrigation requirements in Norse Greenland. Journal of Archaeological Science, 33, 1666-1679.

Adderley, W.P., Simpson, I.A., \& Davidson, D.A. (2002). Colour description and quantification in mosaic images of soil thin sections. Geoderma, 108, 181-192.

Adderley, W.P., Simpson, I.A., Lockheart, M.J., Evershed, R.P., \& Davidson, D.A. (2000). Modeling traditional manuring practice: Soil organic matter sustainability of and early Shetland community? Human Ecology, 28, 415-431.

Aldred, O. (2004). Archaeological investigations, Höfðagerði, Núpar, 2003. Interim Report. Reykjavík: Fornleifastofnun Íslands FS227-02252.

AOAC. (2000). Official methods of analysis of AOAC International, 17th ed. (W. Horwitz, Ed.). Gaithersburg, MD: AOAC International.

Bergpórsson, P. (1969). An estimate of drift ice and temperature in Iceland in 1000 years. Jökull, 19, 95-101.

Bergpórsson, P. (1988). The effects of climatic variations on agriculture in Iceland. Section 2. The effects on agricultural production. In M.L. Parry, T.R. Carter, \& N.T. Konijn (Eds.), Impacts of climatic variations on agriculture. Vol. 1 (pp. 415-444). Dordrecht, Kluwer.

Bjarnason, T. (1912). Um fóðurforðabúr [On fodder stores]. Búnaðarrit, 26, 257-281.

Bjornsson, H., \& Jonsson, T. (2004). Climate and climatic variability at Lake Mývatn. Applied Ecology, 38, 129-144.

Bullock, P., Federoff, N., Jongerius, A., Stoops, G., Tursina, T., \& Babel, U. (1985). Handbook for soil thin section description. Wolverhampton: Waine Research Publications.

Dugmore, A.J., Church, M.J., Buckland, P.C., Edwards, K.J., Lawson, I, McGovern, T.H., Panagiotakopulu, E., Simpson, I.A., Skidmore, P., \& Sveinbjarnardóttir, G. (2005). The Norse landnám on the North Atlantic islands: An environmental impact assessment. Polar Record, 41, 21-37

Edwards, K.J., Borthwick, D., Cook, G., Dugmore, A.J., Mairs, K.-A., Church, M.J., Simpson, I.A., \& Adderley, W.P. (2005). A hypothesis-based approach to landscape change in Suðuroy, Faroe Islands. Human Ecology, 33, 621-650.

Eggertsson, T. (1998) Sources of risk, institutions for survival, and a game against nature in premodern Iceland. Explorations in Economic History, 35, 1-30.

Einarsson, A., Hansson, O., \& Vésteinsson, O. (2002). An extensive system of medieval earthworks on northeast Iceland. Archaeologia Islandica, 2, 61-73.

Einarsson, M.Á. (1979) Climatic conditions of the Lake Mývatn area. Oikos, 32, 29-37.

Elkington, T.T., \& Jones, B.M.G. (1974). Biomass and primary productivity of birch (Betula pubescens s. lat.) in south-west Greenland. Journal of Ecology, 62, 821-830.

ESRI. (2006). ArcGIS 9.2 Manual. Redlands, CA: ESRI Inc.

Friðriksson, A., Vésteinsson, O., \& McGovern, T.H. (2004). Recent investigations at Hofstaðir, northern Iceland. In R.A. Housley, \& G. Coles (Eds.), Atlantic connections and adaptations: Economies, environments and subsistence in lands bordering the North Atlantic (pp. 191-202). Oxford: Oxbow Rooks.

Fu, P., \& Rich, P.M. (2002). A geometric solar radiation model with applications in agriculture and forestry. Computers and Electronics in Agriculture, 37, 25-35.

Gansum, T., Jerpåsen, G.B., \& Keller, C. (1997). Arkeologisk landskapsanalyse med visuelle metoder. AmS-Varia Series 28. Stavanger: Arkeologisk museum i Stavanger. 
Guðmundsson, H.J. (1997). A review of the Holocene environmental history of Iceland. Quaternary Science Reviews, 16, 81-92.

Hodgson, J.M. (1976). Soil survey field handbook. Technical Monograph No. 5. Harpenden: Soil Survey of England and Wales.

IUSS Working Group WRB. (2006). World reference base for soil resources 2006, 2nd ed. World Soil Resources Reports No. 103. Rome: FAO.

Jóhannesson B. (1960). Íslenskur jarðvegur [Icelandic soils]. Reykjavik: Bókarútgáfa Meningarsjóðs.

Kelly, R.H., Parton, W.J., Crocker, G.J., Grace, P.R., Klír, J., Körschens, M., Poulton, P.R., \& Richer, D.D. (1997). Simulating trends in soil organic carbon in long-term experiments using the CENTURY model. Geoderma, 81, 75-90.

Klute, A. (Ed.). (1986). Methods of soil analysis. Part 1. Agronomy 9. Madison, WI: ASA/SSSA.

Körschens, M. (1998). Soil organic matter and sustainable land use. Advances in GeoEcology, 31, 423-430.

Kumar, L., Skidmore, A.K., \& Knowles, E. (1997). Modelling topographic variation in solar radiation in a GIS environment. International Journal of Geographical Information Science, 11, 475-497.

Lucas, G. (Ed.). (2003). Hofstaðir 2002. Interim report. Reykjavík: Fornleifastofnun Íslands FS193-910110.

McCune, B., \& Keon, B. (2002). Equations for potential annual direct incident radiation and heat load. Journal of Vegetation Science, 13, 603-606.

McGovern, T.H., Vésteinsson, O., Friðriksson, A., Church, M., Lawson, I., Simpson, I.A., Einarsson, Á., Dugmore, A., Cook, G., Perdikaris, S., Edwards, K.J., Thomson, A.M., Adderley, W.P., Newton A., Lucas, G., Edvardsson, R., Aldred, O., \& Dunbar, E. (2007). Landscapes of settlement in northern Iceland: Historical ecology of human impact and climate fluctuation on the millennial scale. American Anthropologist, 109, 27-51.

Metherell, A.K., Harding, L.A., Cole, C.V., \& Parton, W.J. (1993). CENTURY soil organic matter model environment agroecosystem version 4.0 technical documentation. Great Plains System Research Unit Technical Report No. 4. Fort Worth, CO: USDA-ARS.

Murphy, C.P. (1986). Thin section preparation of soils and sediments. Berkhamsted, U.K.: AB Academic Publishers.

Nelson, D.W., \& Sommers, L.E. (1982). Total carbon, organic carbon and organic matter. In A.L. Page, R.H. Miller, \& D.R. Keeney (Eds.), Methods of soil analysis, Part 2, Chemical and microbiological properties (pp. 539-579). Madison, WI: American Society of Agronomy.

Ogilvie, A.E.J. (1984). The past climate and sea-ice record from Iceland, Part 1: Data to A.D. 1780. Climate Change, 6, 131-152.

Ogilvie, A.E.J., Barlow, L.K., \& Jennings, A.E. (2000). North Atlantic climate c. AD 1000: Millennial reflections on the Viking discoveries of Iceland, Greenland and North America. Weather, 55, 34-45.

Ovington, J.D., \& Madgwick, H.A.I. (1959). The growth and composition of natural stands of birch. I. Drymatter production. Plant and Soil, 10, 271-283.

Parton, W.J., Stewart, J.W.B., \& Cole, C.V. (1988). Dynamics of C, N, P and S in grassland soils. A model. Biogeochemistry, 5, 109-131.

Parton, W.J., Schimel, D.S., Cole, C.V., \& Ojima, D.S. (1987). Analysis of factors controlling soil organic matter levels in Great Plains grasslands. Soil Science Society of America Journal, 51, 1173-1179.

Reilly, J.M., \& Fuglie, K.O. (1998). Future yield growth in field crops: What evidence exists? Soil and Tillage Research, 47, 275-290.

Shiel, R.S., \& Hopkins, D.W. (1991). Effect of long-term fertiliser and manure treatments on the botanical composition of the Palace Leas meadow hay plots. North of England Soils Discussion Group Proceedings, 26, 35-56.

Sigurgeirsson, M. (1995). Hofsstaðir í Mývatnssveit: Könnun á gjóskulögum vegna fornleifarannsókna sumarið 1995. In A. Friðriksson \& O. Vésteinsson (Eds.), Fornleifarannsóknir á Hofstöðum í Mývatnssveit 1995. Reykjavík: Fornleifastofnun Íslands FS011-91024.

Sigurgeirsson, M. (2001). Greinargerð um gjóskulög. In O. Vésteinsson (Ed.), Archaeological investigations at Sveigakot, 1998-2000. Reykjavík: Fornleifastofnun Íslands FS134-00211.

Simpson, I.A., Adderley, W.P., Guðmundsson, G., Hallsdóttir, M., Sigurgeirsson, M.Á., \& Snæsdóttir, M. (2002). Soil limitations to agrarian land production in pre-modern Iceland. Human Ecology, 30, 423-443.

Simpson, I.A., Guðmundsson, G., Thomson, A.M., \& Cluett, J. (2004). Assessing the role of winter grazing in historic land degradation, Mývatnssveit, northeast Iceland. Geoarchaeology, 19, 471-502. 
Simpson, I.A., Milek, K.B., \& Guðmundsson, G. (1999). A reinterpretation of the great pit at Hofstaðir, Iceland using sediment thin section micromorphology. Geoarchaeology, 14, 511-530.

Simpson, I.A., Vésteinsson, O., Adderley, W.P., \& McGovern, T.H. (2003). Fuel resources in landscapes of settlement. Journal of Archaeological Science, 30, 1401-1420.

Soil Survey Staff. (1998). Keys to soil taxonomy. Blacksburg, VA: Pocahontas Press.

Stoops, G. (2003). Guidelines for analysis and description of soil and regolith thin sections. Madison, WI: Soil Science Society of America.

Sveinbjörnsdóttir, Á.E. (1993). Fornveðurfar lesið úr ískjörnum [Historical climate read from ice cores]. Náttúrufæðingurinn, 62, 99-108.

Thomson, A., \& Simpson, I.A. (2007). Modeling historic rangeland management and grazing pressures in landscapes of settlement. Human Ecology, 35, 151-168.

Thorvaldsson, G., Haahr, P.T., \& Høegh, K. (2000). Growth, development and nutritional value of grass species and varieties cultivated in Greenland, Iceland and the Faroe Islands, 1996-1998. RALA Report 206. Reykjavík: Agricultural Research Institute. Thorvaldsson, G., \& Martin, R.C. (2004). Growth response of seven perennial grass species to three temperature regimes applied at two growth stages. Acta Agriculturae Scandinavica B, 54, 14-22.

Vésteinsson, O. (1998). Patterns of settlement in Iceland. A study in prehistory. SagaBook of the Viking Society, 25, 1-29.

Vésteinsson, O. (2000). The archaeology of Landnám. Early settlement in Iceland. In W.W. Fitzhugh \& E.I. Ward (Eds.), Vikings. The North Atlantic saga (pp. 164-174). Washington DC: Smithsonian Institute Press.

Vésteinsson, O., McGovern, T.H., \& Keller, C. (2002) Enduring impacts: Social and environmental aspects of Viking age settlement in Iceland and Greenland. Archaeologica Islandica, 2, 98-136.

Vésteinsson, O. (Ed.). (2004). Landscapes of settlement: Reports on investigations at five medieval sites in Mývatnssveit. Reykjavík: Fornleifastofnun Íslands FS218-02261.

\section{Received 5 November 2007}

Accepted for publication 10 March 2008

Scientific editing by Carl Lipo 